\title{
Rzeźba Chrystusa z grupy Koronacji Marii z dawnego ołtarza głównego kościoła Wniebowzięcia Najświętszej Marii Panny w Toruniu. Zagadnienie stylu
}

7 achowana część imponującego retabulum z ok. 1370-1390 r. z dawUnego ołtarza pofranciszkańskiego kościoła w Toruniu cieszy się w literaturze przedmiotu uznaniem ze względu na klasę artystyczną, jak i rozbudowany program teologiczny. O ile malowane kwatery były przedmiotem dużego zainteresowania badaczy, o tyle jedynej pozostałości rzeźbionej szafy - figurze Chrystusa zasiadającego na tronie (il. 1) - poświęcono dotąd niewiele uwagi (choć - przy nierozpoznanej w pełni genezie artystycznej nastawy - dobrze zachowana rzeźba mogłaby okazać się pomocna w rozstrzygnięciu tego problemu $)^{1}$.

Zagadnienie to będzie rozpatrywane przy założeniu, że omawiana figura mogła należeć do wspomnianego wyżej zespołu ołtarzowego. Niestety, nie możemy stwierdzić tego z cała pewnościa, por. Z. Białłowicz-Krygierowa, Studia nad snycerstwem XIV w. w Polsce, c\%. 1, Poczatki ślaskiej tradycji ottarza szafowego, Katalog, seria: „Monografie Muzeum Narodowego w Poznaniu", t. 17, Poznań 1981, s. 18, i nie jest możliwe rozstrzygnięcie problemu pochodzenia rzeźby na podstawie zachowanych źródeł. Jednak za przyjętym tutaj założeniem może przemawiać hipoteza związku tematu Koronacji Marii z jej Wniebowzięciem, jako rozwinięciem znaczenia tego pierwszego - „Die mit der »Assumptio Mariae« verbundene »Coronatio und die Coronatio Mariae konnen als ideale Bildinterpretation des Patroziniums gelten” (I. Flor, Mariae Krönung im Wiener Neustädter Retabel, „Österreichische Zeitschrift für 
Dziejów tego zabytku niestety nie można dokładnie odtworzyć z powodu nielicznych źródeł wzmiankujących ołtarz ${ }^{2}$. Pierwszy zachowany opis głównego retabulum, autorstwa burmistrza Torunia - Johanna Baumgarte-

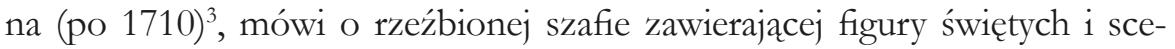
nę Narodzenia Chrystusa w części środkowej. Informacja o rzeźbionych figurach Chrystusa i Marii mieszczących się w ołtarzu: „Ołtarz wielki składany, foris malowana Męka Pańska intus Christus cum Beatissima Matre, a latere ex utraque parte po trzy Osoby rznięte Snycerską robotą [...]", znajduje się w kronice toruńskich bernardynów z $1724 \mathrm{r}^{4}{ }^{4} \mathrm{~W} 1731 \mathrm{r}$. ołtarz został rozebrany; malowane kwatery zaadaptowano do nowej funkcji drzwi Grobu św. ${ }^{5}$, natomiast losów rzeźbionej szafy ołtarzowej nie znamy od tamtej pory aż do początków XX w.

Kunst und Denkmalpflege", H. 1/2, Wien 1996, s. 35-58, s. 42) - a co odpowiada wezwaniu kościoła w Toruniu i grupy Koronacji Marii jako kulminacji programu ikonograficznego retabulum.

2 Przyczyną lakonicznych opisów ołtarza mogła być niekompletność wyposażenia rzeźbiarskiego szafy ołtarzowej już w początkach XVIII w., u: T. Dobrzeniecki, Malarstwo tablicowe, Katalog zbiorów Muzeum Narodowego w Warszawie, Galeria Sztuki Średniowiecznej, t. 1, Warszawa 1972, s. 113. Mimo niejednoznacznie brzmiących zapisów źródłowych pochodzenie rzeźby z kościoła Wniebowzięcia NMP w Toruniu nie budziło wattpliwości. Podobnie jak jej pierwotna przynależność do grupy Koronacji Marii.

3 Cały opis podaje J. H. Zernecke, Thornische Chronica, wyd. 2, Berlin 1727, s. 10-11; por. fragment u: K. Steinbrecht, Thorn im Mittelalter: ein Beitrag zur Baukunst des Deutschen Ritterordens, Berlin 1885, s. 39, podaje przy tym datę 1680(!); T. Dobrzeniecki, op. cit., s. 111; R. Heuer, Die Werke der bildenden Kunst und des Kunstgewerbes in Thorn bis zum Ende des Mittelalters, "Mitteilungen des Coppernicus- Verein fur Wissenschaft und Kunst zu Thorn", H. 24, Thorn 1916, nr 3, s. 73-130, s. 124, określa tekst Baumgartena jako „nicht ganz klar”; A. Semrau, Die Grabdenkmäler der Marienkirche zu Thorn, "Mitteilungen des Copernicus - Vereins fur Wissenschaft und Kunst zu Thorn", H. 7, hrsg. Arthur Semrau, Thorn 1892, s. 7, przytacza również opis Muckendorfa już z 1637 r., w którym nie ma jednoznacznej informacji o rzeźbionej części; por. też u: T. Dobrzeniecki, op.cit., s. 112.

4 K. Kantak, Z kroniki bernardynów toruńskich, „Zapiski Towarzystwa Naukowego w Toruniu", t. 1, nr 9, Toruń 1910, s. 212-217, s. 214. Bernardyni zinwentaryzowali zastane wyposażenie przy przejmowaniu kościoła z rąk protestantów, por. u: B. Dybaś, Inwentarz kościoła NMP i budynków klasztornych, spisany pray przejmowaniu ich przez bernardynów w 1724 r., [w:] Miscelanea źródtowe do historii sqtuki Torunia, oprac. B. Dybaś, M. Farbiszewski, Wrocław 1989, s. 163-170, s. 163.

5 Por. B. Schmid, Die Denkmalpflege in der Provinz. Westpreussen im Jahre 1905. Bericht an die Provinzialkommission zur Verwaltung der westpreussischen Provinzialmuseen zu Dan₹ig, 
Informacja dotycząca tej konkretnej figury Chrystusa, identyfikowanej jako jedyna pozostałość szafy dawnego ołtarza franciszkańskiego, pojawia się po raz pierwszy dopiero w 1907 r. u Bernharda Schmida ${ }^{6}$. W 1935 r. ołtarz wywieziono do Warszawy na „Wystawę Polskiej Sztuki Gotyckiej”, gdzie malowanym kwaterom ołtarza towarzyszyła również rzeźba Chrystu$\mathrm{sa}^{7}$. Z Warszawy rzeźba powróciła do zakrystii kościoła, w której pozostała tylko do 1936 r.; potem przeniesiono ją do pałacu biskupiego w Pelplinie i następnie do tamtejszego Muzeum Diecezjalnego ${ }^{8}$, w którym jest eksponowana do dziś.

Renowacjom poddano głównie kwatery ołtarza. W przypadku rzeźby były to jedynie zabiegi konserwatorskie o charakterze zachowawczym, przeprowadzone w 2000 r. ${ }^{9}$ Już na pierwszym zdjęciu zabytku zamieszczonym przez Schmida w 1907 r. brakuje figurze obu dłoni i części korony ${ }^{10}$.

Danzig 1907, s. 8; idem, Der alte Hochaltar in St.-Marien, "Mitteilungen des CoppernicusVereins fur Wissenschaft" und Kunst zu Thorn", H. 15, hrsg. Arthur Semrau, nr 3, Thorn 1907, s. 40-42, s. 40, 41.

6 Ibidem, s. 41 (wraz z il.). Informację o miejscu przechowywania rzeźby - w zakrystii jej macierzystego kościoła - podaje dopiero: R. Heuer, op. cit., nr 2, s. 39-70, s. 66; wspominają o tym również przedwojenne przewodniki po Toruniu: Führer durch Thorn und seine Umgebung, [b.a.], Thorn 1917, s. 49: dokładnie „auf dem Sakristeischrank”; M. Sydow, Toruń. Jego dzieje $i$ zabytki, Toruń 1929, s. 98; Z. Knothe, Toruń. Stolica Pomorza. Pržewodnik po mieście, Toruń 1934, s. 80.

Katalog tej wystawy sporządził: M. Walicki, Polska sætuka gotycka, Katalog wystawy zorganizowanej przez Towarzystwo Opieki nad Zabytkami Przeszłości w Warszawie, kwiecień-maj 1935, Warszawa 1935, s. 17.

8 R. Ciecholewski, Quis ut Deus: Schätze aus dem Diözesanmuseum Pelplin. Kunst zur Zeit des Deutschen Ordens, Lüneburg 2000 s. 106; J. Domasłowski, Wyposażenie wnetrza, [w:] Kościót Najświętszej Marii Panny w Toruniu, seria: „Zabytki Polski Północnej”, nr 10, red. J. Domasłowski, J. Jarzewicz, Toruń 1998, s. 84-172, s. 88; karta muzealna zabytku dostępna in situ podaje sprzeczne informacje z ww. literatura, a mianowicie, że w zakrystii kościoła rzeźba przetrwała do 1939 r., a dopiero po wojnie trafiła do zbiorów Muzeum Diecezjalnego.

9 Przeprowadziła je mgr Tatiana Srokowska, tj. „oczyszczenie z zabrudzeń powierzchniowych, podklejanie warstwy malarskiej wraz zaprawa, impregnacja”. Informacje te podaje karta muzealna zabytku.

10 B. Schmid, Der alte Hochaltar in St.-Marien, il. na s. 41. Na podstawie zdjęć można jedynie wywnioskować, że w przedziale czasowym 1939-1982 powstały ubytki w partii podstawy i stóp: wg K. H. Clasen, Die mittelalterliche Bildhauerkunst im Deutschordensland Preussen. Die Bildwerke bis zur Mitte des 15. Jabrhunderts. Tafeln, Bd. 2, Berlin 1939 il. 244 (partia stóp była jeszcze kompletna). Przynajmniej od czasu założenia przez Romana Cie- 
Figura Chrystusa zasiadającego na tronie jest wykonana z drewna, ma $72 \mathrm{~cm}$ wysokości ${ }^{11}$. Jako element szafy ołtarzowej jest półplastyczna, o niewielkiej głębokości, od tyłu silnie wydrażona na całej wysokości tak, że drewniany materiał tworzy formę $\mathrm{w}$ rodzaju łupiny ${ }^{12}$. Rzeźbę skonstruowano z wielu części ${ }^{13}$. Poza brakiem obu dłoni ma nieliczne ubytki ${ }^{14}$. W pełni czytelnej kolorystyce polichromii, zapewne wtórnej, przeważaja złocenia szaty i korony; podbicie tkaniny wyeksponowano czerwienia. Karnacja Chrystusa jest jasna, włosy i broda brunatno-czarne, usta czerwone, a kształt brwi i oczu podkreślono ciemnymi, wyrazistymi liniami.

Chrystus odziany jest w dekoracyjnie udrapowaną, dwuwarstwową szatę: długą tunikę i narzucony na nią płaszcz na wzór rzymskiej togi. Zasiada frontalnie na prostokatnej ławie, ze stopami opartymi na płaskiej podstawie zespolonej z siedziskiem. Prawą rękę ma uniesioną i ugiętą w łokciu, zaś lewą lekko oparta na nodze. Głowa jest łagodnie zwrócona i pochylona ku lewemu barkowi.

Bryła rzeźby od przodu prezentuje się jako bardzo plastyczna, dopiero w widoku profilowym ujawnia się niewielka głębokość reliefu ${ }^{15}$ (il. 2).

cholewskiego w 1982 r. karty muzealnej zabytku (wraz ze zdjęciem), brakuje rzeźbie prawej stopy, dużego palca lewej stopy i fragmentu podstawy.

11 Wysokość figury podaje karta muzealna zabytku, dostępna in situ.

12 Lepiej widać to w partii korpusu, szczególnie klatki piersiowej i ramion. Taki wymiar podaję w przybliżeniu za kartą muzealną zabytku. Największa głębokość jest w partii kolan, płytsza w górnej części - ok. $10 \mathrm{~cm}$.

13 Do zasadniczej bryły rzeźby dodano cały przód głowy zespolony z dwóch części i wyrzeźbiony wraz z podstawą korony. Patrząc z góry, na podstawie korony dostrzegalny jest zarys dwóch prostokątnych zaślepień (różnej wielkości, o wspólnym środku) - być może są to ślady po zaczopowaniu. Twarz przytwierdzono na linii włosów i w miejscu styku głowy z szyją. Do korpusu przyłączono prawą rękę wraz z puklami włosów, złożoną jeszcze z dwóch kawałków: podwinięcie rękawa wraz z częścią przedramienia, obie dłonie (pozostały ślady łączeń na kołeczki). Z tyłu łączenie ręki z korpusem wzmocniono listwa. Partię stóp i podstawy składającą się z sześciu części przytwierdzono do siedziska. Ponadto można jeszcze odczytać dołączenie lewego boku tronu. Rozpoznanie miejsca łączeń utrudnione jest z powodu polichromii i spękań drewna.

14 Brak górnej części korony (również łączonej na kołeczki), większej części prawej stopy, palca lewej stopy i fragmentów podstawy z leżącymi na niej fałdami szaty. Partia na wysokości stóp jest niemal pozbawiona polichromii.

15 Prawy bok figury ma łagodniejszy, bardziej miękki i zaokraglony obrys w stosunku do lewego, ostrzejszego, przełamanego pod kątem prostym na wysokości łączenia 
Efekt rozbudowanej przestrzennie bryły uzyskano poprzez skróty perspektywiczne - stosowanie kierunków diagonalnych tworzących iluzję głębi ${ }^{16}$.

Długi płaszcz oplata obficie niemal całą sylwetkę Chrystusa. Część materiału, rozpoczynając konfigurację układu, owija prawą rękę grubą warstwą tkaniny, następnie przełożona przez plecy na lewy bark ${ }^{17}$, okrywając też druga rękę, przechodzi w poprzek korpusu, i znowu po prawej - wykłada się na siedzisku i nodze jedną połą odwrócona podbiciem. Chrystus siedzi na drugiej pole okrywającej lewe kolano, jednocześnie „zlewającej się” z ta po przeciwnej stronie ${ }^{18}$. Szata przylega do ciała, zaznaczając kształt ud i kragłego brzucha. Spływ tkaniny okrywającej lewą rękę, wywijający się u góry półkoliście czerwonym podbiciem, został gęsto zmarszczony plastycznymi fałdkami. Ich kontynuacją są poprzeczne, półkoliście opasujące korpus grzbiety płytkich, graficznych fałdek koszowych. Wykładają się one na udach gęstymi fałdowaniami. Opadający materiał tworzy między kolanami i z boku lewej nogi głębsze fałdy koszowe. Poły płaszcza spływaja z kolan haptycznymi, rurkowymi fałdami sięgającymi kostek. Tunika uwidacznia się spod wierzchniego odzienia jedynie w partii klatki piersiowej, stóp i w miejscu częściowo odsłoniętego prawego przedramienia. U góry odsłania szyję półkoliście zaokraglonym wycięciem ${ }^{19}$. U dołu częściowo otula stopy, a pomiędzy nimi wykłada się trzema długimi fałdami.

nóg i korpusu. Względem tak małej głębokości bryły korpusu głowa została wyraźnie „wypchnięta” ku przodowi.

16 Pulpitowe pochylenie ku widzowi wąskiej, blokowej ławy i jej skośny, lekko zaokraglony lewy bok (prawy bok ławy jest wtórnie prosto ucięty); posadowienie Chrystusa $\mathrm{w} 3 / 4$ względem tronu (jest to widoczne jedynie w widoku od góry); inny kąt ułożenia nóg względem siedziska, tj. lewe udo pod kątem prostym, prawe - osadzone wyżej w cofniętym biodrze i ustawione skośnie ku dołowi; nierównolegle rozstawione, dynamicznie odwrócone do zewnątrz stopy i cofnięte ku siedzisku; ruch prawej ręki z wysuniętym przedramieniem do zewnątrz; skierowanie i pochylenie głowy ku lewej stronie. Przy tak wielu zastosowanych skrótach perspektywicznych optymalny punkt prezentacji figury znajduje się powyżej wzroku widza, jednocześnie monumentalizujący wizualny efekt.

${ }_{17}$ Brak wyraźnej granicy pomiędzy dwiema warstwami szaty może być spowodowany zmianą pierwotnej polichromii, która zarysowywałaby podział (lamówkę płaszcza) kolorystycznie.

18 Uniemożliwia to dokładne odczytanie przebiegu krawędzi tych dwóch części materiału.

19 Zaznaczając tym samym kości obojczykowe. 
Głowa została niezwykle szczegółowo opracowana. Twarz jest owalna, miękko wymodelowana, z naturalnie zaznaczoną strukturą anatomiczna. Proste czoło zarysowane półkoliście linią włosów ma zaznaczone fałdy skórne: zbiegające się u nasady nosa i pogrubiające łuki brwiowe. Gałki oczne sa silnie wypukłe, niemal „wypychające” powieki. Prosty nos ma wyraźnie wydobyte skrzydełka dosyć głębokimi fałdami nosowo-wargowymi, ujmującymi jednocześnie wąskie i lekko rozchylone usta. Kości policzkowe uwypuklaja poprzeczne bruzdy, które wraz z fałdami schodzącymi ku kącikom ust, dają odczucie nieco „ściagniętej”, dojrzałej skóry. Głowę okalaja włosy i niedługa broda, dekoracyjnie ufryzowane, głównie z pojedynczych, spiralnie skręconych pukli. Symetryczny zarost ujmuje twarz stopniowo powiększającymi się addycyjnymi lokami, na brodzie tworzącymi układ w kształcie litery „, $\Omega$ ”. Korkociagowe formy długich włosów zebranych na wysokości szyi opadają na ramiona i okalaja twarz. Resztę włosów wyróżniono jako zwartą masę o pofalowanej powierzchni, układająca się nad linią uszu. Zarówno zarost, jak i włosy rozrzeźbione są graficznie, falistymi żłobieniami wyodrębniającymi dosyć szerokie pasma.

Stan badań nad rzeźbą Chrystusa nie jest obszerny, mimo że wzmianki o niej są dosyć liczne. Pierwsze informacje w literaturze na temat tej figury pojawiły się za sprawa Bernharda Schmida w artykule wydanym w serii „Mitteilungen des Coppernicus -Vereins für Wissenschaft und Kunst zu Thorn” w roku 1907 20, dotyczącym dawnego ołtarza głównego z kościoła franciszkańskiego w Toruniu. Poza wspomnianym opublikowaniem zdjęcia rzeźby Chrystusa podał lokalizację figury w obrębie retabulum ${ }^{21}$. Kolejne publikacje ważne dla rozwoju badań nad zabytkiem, to prace syntetyczne omawiające sztukę Torunia i regionu ${ }^{22}$, autorstwa pastora Reinholda Heu-

20 B. Schmid, Der alte Hochaltar in St.-Marien, s. 41.

21 W późniejszej publikacji, z 1913 r. wzmiankował figurę Chrystusa jedynie jako przyczynek na marginesie szerszego tematu: idem, Die gotischen Bildwerke der St. Johanniskirche, "Mitteilungen des Coppernicus - Vereins fur Wissenschaft und Kunst zu Thorn", H. 21, hrsg. A. Semrau, nr 1, Thorn 1913, s. 8-14, s. 13.

22 Obok wyżej wymienionych są to: B. Schmid, Die bildende Kunst in Preussen zur Zeit des Deutschen Ritterordens, [w:] Die Provinz. Westpreussen in Wort und Bild, Danzig 1915, s. 442-459, s. 445; G. Chmarzyński, Toruń dawny i dzisiejszy, Toruń 1933, s. 15, il. s. 44; K. H. Clasen, op.cit., Bd. 1, s. 196-197; B. Schmid, Baukunst und bildende Kunst zur Or- 
era „Die Werke der bildenden Kunst und des Kunstgewerbes in Thorn bis zum Ende des Mittelalters”23, ks. Bolesława Makowskiego „Sztuka na Pomorzu”24 i przede wszystkim - Gwidona Chmarzyńskiego „Sztuka w Toruniu"25. Często rzeźba Chrystusa wzmiankowana była przy okazji badań nad kwaterami ołtarzowymi ${ }^{26}$, tak więc spora grupę publikacji stanowią opracowania malarstwa gotyckiego w Polsce i regionie ${ }^{27}$. W tych pracach rzeźba odnotowana jest najczęściej przy rekonstrukcji budowy retabu-

denszeit, [w:] Deutsche Staatenbildung und deutsche Kultur im Preussenlande, Königsberg 1931, s. $116-150$, s. 147.

23 R. Heuer, op. cit., nr 2, s. 66; ibidem, nr 3, s. 76, 124.

24 B. Makowski, Sztuka na Pomorzu. Jej dzieje i zabytki, Toruń 1932, s. 48.

25 G. Chmarzyński, Sztuka w Toruniu. Zarys dziejów, [w:] Drieje Torunia, red. K. Tymieniecki, Toruń 1933, s. 471-544, s. 502-503.

${ }^{26}$ Kwatery ołtarzowe powstawały etapowo, a datowane sa nawet od ok. poł. XIV w. do pocz. XV w. Wyróżniono co najmniej trzy „ręce”: 1. Przybyły z Czech autor najstarszej części kwater (najwyższej klasy artystycznej) wykazuje najsilniejszy związek z malarstwem, tzw. Mistrza z Wyższego Brodu i Mistrza Teodoryka (uroczyste otwarcie); 2. Posiada cechy czeskiej sztuki, jednak wraz z innymi, bliżej nieokreślonymi naleciałościami. Jest słabszej klasy (,pierwsze” zamknięcie); 3. O wpływach turyńskich i dolnosaksońskich, też o znamionach sztuki Konrada von Soest („drugie” zamknięcie), por. u: A. S. Labuda, Malarstwo tablicowe państwa krazyżackiego drugiej połowy XIV wieku, [w:] Malarstwo gotyckie na Pomorzu Wschodnim, seria: „Prace Komisji Historii Sztuki. Poznańskie TPN”, t. 17, red. J. Domasłowski, A. Karłowska-Kamzowa, A. S. Labuda, Warszawa 1990, s. 66-90, s. 68-75; idem, Malarstwo tablicowe na Pomorzu Wschodnim, [w:] Malarstwo gotyckie w Polsce, t. 2, Synteza, seria: „Dzieje Sztuki Polskiej”, cz. 3, red. A. S. Labuda, K. Secomska, Warszawa 2004, s. 333-36, s. 336; stan badań skrzydeł ołtarzowych u: T. Dobrzeniecki, op.cit., 100-117; Kościót franciszkanów pw. Panny Marii, Justyna Zdrajkowska], Malarstwo gotyckie w Polsce, Katalog zabytków, seria: „Dzieje Sztuki Polskiej”, cz. 3, red. A. S. Labuda, K. Secomska, t. 2, Warszawa 2004, s. 270-274.

27 Przede wszystkim sa to obszerne prace syntetyczne: G. Brutzer, Mittelalterliche Malerei im Ordenslande Preussen, Danzig 1936, s. 47-51; „Malarstwo gotyckie na Pomorzu W schodnim”" (A. S. Labuda, Malarstwo tablicowe państwa krayżackiego drugiej połowy XIV wieku, s. 69, 71); „Malarstwo gotyckie w Polsce" (tenże, Malarstwo tablicowe na Pomorzu W schodnim, s. 333); katalogi, np. monumentalny „Malarstwa gotyckiego w Polsce” (Kościót franciszkanów pw. Panny Marii [J. Zdrajkowska], Malarstwo gotyckie w Polsce, t. 2, s. 270-274); T. Dobrzeniecki, op.cit., s. 113, 115, 116. Obok wyżej wymienionych są to: T. Dobrzeniecki, Sztuka sakralna w Polsce. Malarstwo, Warszawa 1958, s. 336: pisze jedynie o rzeźbionej Koronacji Matki Boskiej w części środkowej ołtarza; A. Stange, Deutsche Malerei der Gotik. Die Zeit von 1350 bis 1400 , Bd. 2, Nendeln 1969, s. 80, 83; rzeźba wspomniana była w jednym inwentarzu: Georg Dehio, bearb. G. E., S. Bernhard, T. Grete, Deutschordensland Preussen, seria: "Handbuch der Deutschen Kunstdenkmäler", München 1952, s. 77. 
$\operatorname{lum}^{28}$ i jego ikonografiii ${ }^{29}$, wymieniana w katalogach wystaw ${ }^{30}$ i wśród eksponatów Muzeum Diecezjalnego w Pelplinie ${ }^{31}$. Wzmianki o figurze Chrystusa pojawiły się też w licznych pracach o charakterze popularnonaukowym, ukazujących się w latach 90. i na przełomie XX i XXI wieku². Sygnalizowano w nich starsze tezy badaczy, przychylając się ku którejś z nich, ale bez komentarza uzasadniającego wybór ${ }^{33}$.

W dotychczasowej literaturze podjęto w odniesieniu do omawianej tu rzeźby w zasadzie dwa problemy badawcze: rodowód artystyczny i warsztatowy, datowanie. O rodowodzie artystycznym pierwszy wypowiedział się Bernhard Schmid, uznając, że figura Chrystusa wykazuje podobieństwa

${ }^{28}$ Od dawna trwa na ten temat dyskusja w literaturze, por. zestawienie rekonstrukcji u: T. Dobrzeniecki, Malarstwo tablicowe, s. 101; A. S. Labuda, Malarstwo tablicowe państwa kryyżackiego drugiej polowy XIV wieku, s. 69; M. Walczak, [rec.] pracy: „Malarstwo gotyckie na Pomor₹u Wschodnim", red. J. Domasłowski, A. Karłowska-Kamzowa, Adam S. Labuda, Warszawa 1990; „Folia Historiae Artium”, t. 29, Kraków 1993, s. 185-192, s. 189: zaproponował rekonstrukcję szafy ołtarzowej na podstawie ,niewykorzystanego w pełni” inwentarza bernardynów z 1724 r. i nieco wcześniejszego opisu Baumgartena; za to: A. S. Labuda, Chrystus dwunastoletni - Bóg, Nauczyciel. Ze studión nad retabulum franciszkanów toruńskich, [w:] Nobile claret opus. Studia z dziejón squtuki dedykowane Miecaystawowi Zlatowi, Wrocław 1998, s. 106-122, s. 88: pisze, że to „wciąż jest postulatem badawczym”; na ten temat wypowiedział się też Juliusz Raczkowski w referacie wygłoszonym 6 lutego 2015 r. w Instytucie Zabytkoznawstwa i Konserwatorstwa UMK w Toruniu.

29 Por. u: A. S. Labuda, Malarstwo tablicowe państwa krzyżackiego drugiej połowy XIV wieku, s. 70, 71; w jednym przypadku jest to artykuł poświęcony ikonografii kwatery: A. S. Labuda, Chrystus dwunastoletni - Bóg, Nauczyciel. Ze studiów nad retabulum franciszkanów toruńskich, s. 106.

30 M. Walicki, op.cit., s. 17; K. Kluczwajd, Skarby kościoła Mariackiego w Toruniu, Katalog wystawy, Torun 2005, s. 9, 35.

31 R. Ciecholewski, Rz̨eźba gotycka w pelplińskim Muzeum Diecezjalnym, „Studia Pelplińskie", t. 14, Pelplin 1983, s. 307-321, s. 314-315; idem, Skarby Pelplina, wyd. 2, Pelplin 1999, s. 112; idem, Quis ut Deus: Schätze aus dem Diözesanmuseum, s. 106.

32 Są to: J. Domasłowski, op.cit., s. 88; M. Woźniak, Skarby dawnego Torunia, Toruń 1999, s. 66; praca poświęcona Pelplinowi: R. Ciecholewski, Skarby Pelplina, s. 112; J. Raczkowski, Sztuka gotycka w Toruniu, Torun 2003, s. 72; idem, Mistrz. Toruńskich Ukrzyżowań, „Miesięcznik Kulturalno-Informacyjny »Ilustratore”, nr 4, Toruń 2004, s. 11; K. Kluczwajd, op.cit., s. 9, 35; A. Błażejewska, E. Pilecka, Sztuka średniowieczna, [w:] Dzieje sztuki Torunia, red. A. Błażejewska, K. Kluczwajd i in., Toruń 2009, s. 15-186, s. 113, il. 99, s. 116 .

33 Np. u: J. Domasłowski, op.cit., s. 88; A. Błażejewska, E. Pilecka, op.cit., s. 113, il. 99, s. 116 . 
ze stylem „Erfurter Meister der Barfüsserkirche”, szczególnie „Severisarkophages" 34 . Makowski pierwszy pośrednio powiązał rzeźbę ze sztuką lokalną; odwołując się do dwóch zabytków toruńskich: figur Marii i Jana z Ukrzyżowania z kościoła św. Janów oraz krucyfiksu dominikańskiego na Drzewie Życia ${ }^{35}$. Gwido Chmarzyński już bezpośrednio włączył figurę do pracowni lokalnej Madonn Szafiastych ${ }^{36}$ oraz bliskich im stylowo rzeźbionych figur z ołtarza Koronacji Marii na Helu ${ }^{37}$. Clasen jako jedyny zasugerował konkretnego wykonawcę - tzw. Mistrza Ukrzyżowań Toruńskich. Według Clasena jest on autorem przede wszystkim dwóch wspomnianych Ukrzyżowań z Torunia: z kościoła św. Janów i krucyfiksu na Drzewie Życia. Za Makowskim, na podstawie różnic w opracowaniu rzeźb, usytuował Chrystusa z Koronacji pomiędzy starszymi figurami asysty a późniejszym krucyfiksem $^{38}$. Jerzy Domasłowski nazwał rodowód rzeźby Chrystusa „dokładnie nieokreślonym”, skłaniając się ku Czechom ${ }^{39}$. Ciecholewski jako jedyny podją problem możliwości importu tak wysokiej klasy dzieła ${ }^{40}$. Jako

34 B. Schmid, Die gotischen Bildwerke der St. Johanniskirche, s. 13: wprawdzie na poboczu innego tematu, ale odwołując się do zamieszczonej przez siebie ilustracji rzeźby Chrystusa. R. Heuer, op.cit., nr 2, s. 66: poparł tę tezę, wskazując analogie w podobnym typie głowy, brody, modelowaniu szat. Ponadto zasugerował możliwość wykonania dzieła przez warsztat franciszkański: „[...] die preußischen Franziskanerklöster gehörten zur 'Provinz' Sachsen, sodaß künstlerische Einflüsse von dort her nicht auffallend wären”. Schmid swoje spostrzeżenie odnośnie rodowodu artystycznego wzmiankował ponownie w: B. Schmid, Baukunst und bildende Kunst zur Ordenszeit, s. 147.

35 B. Makowski, op.cit., s. 48. Z grupy Ukrzyżowania z kościoła św. Janów w Toruniu zachowały się jedynie figury Marii i Jana, obecnie znajdujące się w tamtejszym Muzeum Okręgowym. Krucyfiks dominikański przeniesiony został do kościoła św. Jakuba w Toruniu.

36 G. Chmarzyński, Sztuka w Toruniu. Zarys dziejów, s. 502-503: jako przykład tej analogii formalnej podaje Boga Ojca z wnętrza Madonny Szafiastej z Rogóźna (obecnie w Germanisches Nationalmuseum w Norymberdze).

37 Ibidem, s. 503. Ołtarz zachowany we fragmentach. Obecnie w Muzeum Narodowym w Gdańsku. Dzieła te określił jako: „lokalną twórczość pruska, parafrazująca czeskie przykłady wczesnego „stylu miękkiego”. Jego zdaniem rzeźba Chrystusa z Torunia była błędnie łączona przez poprzednich badaczy z erfurckim „Severimeister”. Tezę o warsztacie miejscowym poparli też: M. Walicki, op.cit., s. 17; G. Brutzer, op.cit., s. 47; K. H. Clasen, op.cit., s. 196, przy czym ten pierwszy dodał, że będącym „pod wpływem czeskim”.

38 Ibidem, s. 196, 197.

39 J. Domasłowski, op.cit., s. 88; podobnie: R. Ciecholewski, Quis ut Deus: Schätže aus dem Diözesanmuseum, s. 106.

40 Tamże: nieznajdującego analogii wśród XIV-wiecznej snycerki na terenie Prus. 
ostatnie dotąd wypowiedziały się na temat figury Anna Błażejewska i Elżbieta Pilecka, optując za bliżej nieokreślonym rodowodem turyńskim ${ }^{41}$.

Datowanie rzeźby w literaturze mieści się w przedziale od ok. 1370 r. do k. XIV wieku. Schmid w 1913 r. podał jako czas jej powstania 2 poł. XIV wieku ${ }^{42}$. Kilka lat później Heuer wydatował ją na ostatnia tercję XIV wieku43. Chmarzyński (1933) pierwszy podjął się precyzyjniejszego datowania - na ok. $1390 \mathrm{r}^{44} \mathrm{~W}$ karcie muzealnej zabytku, założonej w 1982 r. przez ks. Ciecholewskiego, pojawia się data: ok. 1380 r. Nowsze publikacje w odniesieniu do tej kwestii powtarzają dawne hipotezy ${ }^{45}$. Ostatnio Błażejewska i Pilecka skłoniły się ku dolnej granicy, datując rzeźbę na ok. $1370 \mathrm{r}^{46}$

Choć tytułowa rzeźba nie była dotąd przedmiotem szerszych rozważań, chcąc przyjrzeć się bliżej stylistyczno-warsztatowej genezie figury, warto zwrócić uwagę na kilka dotychczasowych hipotez. One - być może - moga stanowić punkt wyjścia dla dalszych badań.

Tezę Gwidona Chmarzyńskiego o pochodzeniu toruńskiej rzeźby Chrystusa z pracowni Madonn Szafiastych ${ }^{47}$ i ołtarza z Helu ${ }^{48}$, bez po-

41 A. Błażejewska, E. Pilecka, op.cit., s. 113.

${ }^{42}$ B. Schmid, Die gotischen Bildwerke der St. Johanniskirche, s. 13: tę połowę stulecia podaje dla grupy zabytków toruńskich; B. Schmid, Die bildende Kunst In Preussen zur Zeit des Deutschen Ritterordens, s. 445: odwołując się do całego ołtarza, uściśla datę do krótko po 1370 r. w związku z ukończoną budową kościoła.

43 R. Heuer, op.cit., nr 2, s. 66. Rok później przewodnik po Toruniu podaje ostatnią ćw. XIV w., por. Führer durch... [b.a.], op.cit., s. 49.

${ }^{4}$ G. Chmarzyński, Sztuka w Toruniu. Zarys dziejów, s. 502-503; idem, Toruń dawny i dzisiejszy, Toruń 1933, s. 15, il. na s. 44. Za nim tę datę powtarzają: M. Walicki, op.cit., s. 17; K. H. Clasen, op.cit., s. 197.

45 J. Domasłowski, op.cit.: ok. 1380-90 r. (datę zamieszcza pod il. 28); R. Ciecholewski, Quis ut Deus: Schätze aus dem Diözesanmuseum, s. 106: 4 ćw. XIV w.; idem, Skarby Pelplina, s. 112: podaje k. XIV w.; J. Raczkowski, Sztuka gotycka w Toruniu, s. 72 i K. Kluczwajd, op.cit., s. 35: ok. 1390.

46 A. Błażejewska, E. Pilecka, op.cit., s. 116.

${ }^{47} \mathrm{~W}$ literaturze funkcjonuja dwa terminy - „Madonny Szafkowe” i „Madonny Szafiaste", por.: Tadeusz Dobrzeniecki, Maria - Tabernaculum Dei et Verbi, [w:] Sztuka w kregu zakonu krzyżackiego w Prusach i Inflantach, red. M. Woźniak, Toruń 1995, s. 275-278, s. 275. Użyty wyżej termin powtarzam za Chmarzyńskim.

48 Chmarzyński, pisząc jednocześnie o dwóch warsztatach - Madonn Szafiastych i ołtarza z Helu - nie podaje jednoznacznie, na czym miałaby się opierać zależność między nimi. 
dania konkretnej argumentacji, trudno jest przyjąć bez zastrzeżeń. W podanym przez niego przykładzie - Boga Ojca z Tronu Laski we wnętrzu figury z Rogóźna ${ }^{49}$ - nie można dostrzec wyraźnych analogii stylistycznych z rzeźbą toruńskiego Chrystusa. Szata Boga Ojca nie uwidacznia kształtu ciała, jest obfitsza i nieregularnie drapowana, a opadające fałdy są spłaszczone. Twarz jest podłużna, o zapadniętych policzkach, dłuższym nosie, ostrzejszych łukach brwiowych i dolnych powiekach - grubszych, górnych - bardziej wiotkich. Drugi przykład dzieła warsztatu lokalnego - rzeźb z grupy Koronacji Marii z retabulum w Helu ${ }^{50}$ (il. 3) - wydaje się trafniejszy, choć także różni się istotnie opracowaniem od figury toruńskiej. Twarz helskiego Chrystusa jest bardziej wydłużona, wręcz „wyciagnięta”, przez co zaciera się naturalna kostna budowa; jest ostrzej modelowana; ma bardziej wypukłe czoło i znacznie niżej osadzone oczy. Za podobne możemy uznać motywy: zarost z łączonych pukielków zwiększających się stopniowo ku dołowi, włosy rozfalowane żłobieniami i „ściąnięte” na wysokości szyi, jak i szereg szczegółów anatomicznych twarzy - wydatne gałki oczne, wąskie, lekko rozwarte usta, zaakcentowane policzki i fałdy nosowo-wargowe. Podobnie dzieje się w partii szat, tj. różnią się od toruńskich formalnie: są geściej udrapowane, modelowane znacznie graficzniej, fałdy mają ostrzejsze grzbiety $^{51}$. Zadziwiająco wiele zbieżności odnajdziemy pomiędzy figurą helską a typem i konfiguracją szaty Chrystusa z Torunia: podobna ostrą fałdę koszową z lewej strony figury i pomiędzy kolanami, rurkowe zwisy z ko-

49 U pozostałych Madonn Szafiastych z terenu Prus krzyżackich sa to najwyżej podobieństwa pojedynczych motywów. W przypadku Madonn Szafiastych raczej nie można mówić o odrębnej dla nich pracowni, a co za tym idzie stylu znamiennego dla ich całej grupy, tylko o typie przedstawienia i jego czasem dokładnych powtórzeniach.

${ }^{50}$ Z zespołu ołtarzowego zachowały się jeszcze figury czterech św. Dziewic, jednak nie będą one już tutaj materiałem porównawczym ze względu na powtarzalność formy i typu, nieróżniących się zasadniczo pod tym względem od grupy Koronacji. Do tego samego zespołu ołtarzowego włącza się również grupę Zaśnięcia Najświętszej Marii Panny, której Chmarzyński nie uwzględnił w swojej pracy, por. u: Z. Białłowicz-Krygierowa, Studia nad snycerstwem XIV w. w Polsce, Katalog, s. 60-61; M. Jakubek-Raczkowska, Plastyka średniowieczna od XIII do XVI wieku, Katalog wystawy stałej. Muzeum Narodowe w Gdańsku, Gdańsk 2007, s. 54.

51 Należy wziąć pod uwagę uszkodzenia rzeźby, m.in. część ułamanych fałd szaty. Wprawdzie nie przeczy to odmiennemu opracowaniu, ale być może niektóre partie były opracowane bardziej miękko od pozostałych. 
lan materiału o meandrycznej krawędzi, układ stóp i opadanie materiału na podstawę ${ }^{52}$ czy analogiczne wywinięcie podbiciem na klatce piersiowej i fałdkę przy lamówce ${ }^{53}$. To jednak świadczyć może o tym, że posługiwano się w obu przypadkach takim samym schematem figury (włącznie z powtarzaniem poszczególnych motywów), a nie o wytworzeniu ich w tym samym warsztacie ${ }^{54}$.

W przypadku poszukiwań proweniencji artystycznej wśród zabytków sztuki europejskiej przykłady podawane w literaturze, choć niewolne od zastrzeżeń, są znacznie bardziej uzasadnione. Trafnym spostrzeżeniem Bernharda Schmida, podjętym przez Reinholda Heuera, było wykazanie podobieństwa między dziełami tzw. Mistrza Severisarkophages z Erfurtu a rzeźbą Chrystusa z Torunia. Pokrewną cechą dla naszego zabytku jest sposób opracowania szat - relacja dosyć cienkiego, miękkiego materiału względem ciała postaci; w niektórych miejscach tkanina jak gdyby przylega, uwidaczniając je. Szata zdaje się jednak bardziej pofałdowana i plastyczna. Podobne są też pewne motywy: rurkowe zwisy materiału, poprzeczne fałdki w partii korpusu. Również opracowanie głowy wykazuje szereg podobieństw, jednak

52 W tym miejscu fragmenty podstawy i szat są ułamane, ale można dopatrzyć się podobnego zastosowania motywu trzech fałd wykładających się pomiędzy stopami.

${ }_{53} \mathrm{~W}$ odniesieniu do figury Marii z grupy helskiej materiałem porównawczym moga być jedynie szaty powtarzające twardszy modelunek, obfitsze fałdy, szczególnie te wykładające się na nogach. Twarz jest kształtowana na wzór oblicza Madonn na Lwach, dlatego porównania z rzeźbą toruńską są zbędne. Mimo braku bezpośredniej zależności stylistycznej pomiędzy Helem a Toruniem należy przyznać, że jedynie Gwido Chmarzyński podał sugestywne przykłady ze sztuki lokalnej, które trzeba rozważyć jako powiązane w różnym stopniu z rzeźbą Chrystusa.

54 Pomijam opinię Clasena o powiązaniach figury Chrystusa ze sztuka lokalna. Teza zdezaktualizowała się w dużej mierze wskutek podważenia teorii o istnieniu tzw. Mistrza Ukrzyżowań Toruńskich, do którego warsztatu włączał również rzeźbę Chrystusa z kościoła Wniebowzięcia NMP w Toruniu (o niesłusznej tezie Clasena por. m.in. u: J. Raczkowski, Mistrz. Toruńskich Ukrzyżowań, s. 11; A. Błażejewska, E. Pilecka, dz. cyt., s. 147). Autor podaje przykład form szeroko popularnych w sztuce europejskiej ok. 1370-1390 r., niewyznaczających konkretnej drogi artystycznej Mistrza, i dlatego trudno jest wychwycić przekonujące do tej atrybucji analogie, por. K. H. Clasen, op.cit., s. 196: „die Haarbildung aus weichen, in gröseren Abständen gekerbten Wülsten”, s. 197: „klar geformten Einzelmassen $[\ldots],[\ldots]$ gebogene Hautfalte über dem Leib [...], [...] den Anflug von Löwenmadonnenstil”. Pomiędzy tym ostatnim „stylem” a figurą Chrystusa nie widział bezpośrednich zależności. Wyodrębniając te cechy, wykazywał podobieństwa z dziełami śląskimi tego czasu. 
oblicza postaci są bardziej „suche”, pod mocno naciągniętą skórą widoczna jest kostna budowa. Ponadto nie u wszystkich figur pojawiaja się korkociagowe pukle. Jednakże ww. cechy zbieżne ze środowiskiem erfurckim nie przesądzają o pochodzeniu rzeźby Chrystusa z tamtejszych warsztatów.

Chcąc rozstrzygnąć, jaki jest rodowód artystyczny rzeźby Chrystusa w relacji do sztuki lokalnej, należy wpierw odwołać się do artystycznej genezy dawnego ołtarza, którego częścią - jak zakładamy - była omawiana tutaj figura. Istnieje bowiem uzasadnione prawdopodobieństwo, że zespół wykonujący retabulum: malarze i rzeźbiarze wywodzili się z tego samego środowiska artystycznego ${ }^{55}$. Z tego względu nie można pominąć czeskiego malarstwa z ok. połowy XIV wieku, które w istotnym stopniu inspirowało realizacje malowanych kwater. Mogło ono mieć również wpływ na styl snycerki przeznaczonej do tego retabulum. To spostrzeżenie - inspirowaniem się rzeźbiarzy malarstwem - wspiera hipoteza Ivo Hlobila, który zasugerował jako sugestywne analogie - twarze rzeźb Madonny z Klosterneuburga oraz św. Floriana z klasztoru St. Florian w Górnej Austrii, powiązanego z tzw. Mistrzem Madonny z Michle - do oblicza Madonny z Veveří Mistrza z Wyższego Brodu ${ }^{56}$. Wprawdzie badacze wskazywali już na czeską pro-

55 Tworzenie takich malarsko-rzeźbionych nastaw było często praktykowane, przede wszystkim w czasie rozkwitu nastawy ołtarzowej w XIV wieku. Szczególnie nierzadko spotykana była w tego typu nastawach tematyka mariologiczna, a w tym rzeźbiona Koronacja Marii, np. retabulum z Rossow (ok. 1330), Marienstatt, Altenbergu, Oberwesel (ok. 1350), tzw. Ołtarz czeski z katedry w Brandenburgu (ok. 1375/80), ołtarz z Arensee (ok.1380), por. u: N. Wolf, Deutsche Schnitzretabel des 14. Jahrbunderts, Berlin 2002. O zależności rzeźby z malarstwem, która znajduje "najdobitniejszy wyraz w ołtarzu szafowym”, wspomina: Zofia Biattowicz-Krygierowa, Ze studión nad kregiem Madonn na lwach. Motyw i system, [w:] Z dziejów sztuki ślaskiej, red. Zygmunt Świechowski, Warszawa 1978, s. 247-272, s. 257; podaje tam również. nymowny prayktad - obraz Pasji ₹ Kolonii (?) ₹ ok. 1430 r., na którym malarsko przedstawione postacie opatrzone zostaly petnoplastycznymi głowami. Z tych samych pobudek "tamania granic gatunków” mialyby powstawać "plastyczne” malowidła Teodoryka w Karlštejnie, ibidem, s. 257. O bliskich relacjach malarstwa książkowego z rzeźba: Jaromír Homolka, Poznámky ke vývoji českébo a strédoevropskébo rezabárstui 14. Století, [w:] Gotické socharstui a malirstui v severozápadnich Céchách. Sbornike z. kolokvia u prílę̌itosti 70. výroči výstayy Josefa Opitze, Ústí nad Labem 1999, s. 60. Poza tym na uwage zasługuje fakt, że tak starannie, wręcz kunsztownie opracowana figura toruńska była przeznaczona do nastawy ołtarzowej, dlatego można mówić o zatrudnieniu do tej realizacji niepośledniego warsztatu.

56 I. Hlobil, Die Klosterneuburger Löwenmadonna angeblich eine Falschung. Analyse einer falschen Behauptung, „Umění/Art” LIV, Praha 2006, s. 85-98, s. 87. W tej samej pracy podejmuje 
weniencję figury Chrystusa z Torunia, jednak nie podali przykładów dzieł, które skłoniły ich do takiej tezy ${ }^{57}$. Spośród malowideł retabulum najbliższą analogia formalną dla rzeźby są najstarsze kwatery (ok. 1370 r.), tzw. świątecznego otwarcia. Bez wattpienia są one dziełem artysty pochodzącego z Czech, który bezpośrednio zetknął się ze sztuką tzw. Mistrza z Wyższego Brodu $^{58}$. Bliski stylowi rzeźby Chrystusa jest sposób modelowania szat malowanych postaci, bardzo miękko i dekoracyjnie formowanych m.in. u: Boga Ojca z kwatery Trójcy Św. (il. 4), Marii w scenie Pokłonu Trzech Króli. Ponadto analogiczne są motywy, zwłaszcza u Tronującego Boga Ojca: wielowarstwowość szaty, jej meandryczne krawędzie zwieszających się z kolan fałd, fałdy koszowe między kolanami i z boku lewej nogi, podłużne fałdy wykładające się pod stopami, poła płaszcza odwracająca się na udach podbiciem. Już na podstawie powyższych podobieństw, zakładając pochodzenie rzeźby z tego samego „świątecznego" otwarcia retabulum ${ }^{59}$, można sugerować, że to środowisko artystyczne nie było obce twórcy rzeźby Chrystusa. Jeśli tak, należy poszerzyć porównania o „punkt wyjścia” dla

problem fałszerstwa Madonny z Klosterneuburga, przychylając się do tezy o jej autentyczności. O Madonnie z Klosterneuburga także w: idem, Neznámá Madona na lvu od Mistra michelské madony (kolem let 1340-1345), „Umění/Art” LIII, Praha 2006, s. 3-20. Należy przy tym nadmienić, że do pracowni „Mistrza z Michle” włącza się tzw. Madonnę z Broumow (I) z l. 40 XIV wieku, która posiada pewne cechy modelunku rzeźby toruńskiej: dosyć ciągliwą materię szaty o graficznych, drobnych fałdowaniach opasujących korpus i uwidaczniających kształt ciała, por. I. Hlobil, Gotické Madony na lvu. Gotische Löwenmadonnen. Splendor et Virtus Reginae Coeli, Olomouc 2014, il. 34, 35, s. 77.

${ }^{57}$ M. Walicki, J. Domasłowski, r. Ciecholewski, wyrokując jedynie na podstawie „wrażenia”, najpewniej obrali sobie za wytyczny czeski rodowód całego ołtarza. Biorąc pod uwage równocześnie podawana przez nich datę powstania rzeźby Chrystusa - ok. 1390 r. - trzeba uwzględnić dzieła z 2 poł. XIV w. lub nawet z ostatniej ćwierci tego stulecia.

58 Twórca kwater „drugiego otwarcia” (Pasji Chrystusa) również wyjawia w przeważającym stopniu znajomość sztuki czeskiej, lecz już z bliżej nieokreślonymi innymi wpływami. Dzieła „III Mistrza” powstały z inspiracji sztuką Dolnej Saksonii, Turyngii (nie podano konkretnych przykładów) i Konrada von Soest (por. przyp. 26 w niniejszej pracy), którego dzieła, podobnie jak część poliptyku toruńskiego, nie zdradzają analogii ani z kwaterami „I Mistrza”, ani z rzeźbą Chrystusa. Szaty sprawiaja wrażenie cięższych i mniej dekoracyjnych; odmienna jest relacja szat do ciała - nie przylegają do niego, przez co nie uwidaczniaja jego kształtu.

59 Można zwrócić uwagę na uzasadnione wymagania, być może zakonników, stworzenia „świątecznego” otwarcia ołtarza w pewnej mierze jednorodnego, spójnego stylowo. 
jego rodowodu - twórczość Mistrza z Wyższego Brodu. Figura toruńska jest wykonana jako dość płytki relief, dlatego efekt głębi wydobyto w niej, posługując się również środkami stosowanymi w malarstwie. Dzieła czeskiego Mistrza dostarczają szeregu przykładów cech wiążących jego twórczość ze stylem toruńskiej rzeźby Chrystusa. Dysponując różnorodnościa typów przedstawianych przez niego postaci, różnymi konfiguracjami ich szat, możemy dokonać liczniejszych porównań. Obok analogicznie kunsztownego drapowania szat widoczna jest ich podobna relacja względem ciała (il. 1, 5). Podobnie jak w rzeźbie toruńskiej tkanina wydaje się na tyle cienka, by uwidocznić szczupłą sylwetkę postaci. Mimo odmiennych gatunków artystycznych rzeźbę Chrystusa łączy ten sam sposób modelowania szat - miękki i plastyczny, wydobywający głębię za pomoca światłocienia - na tyle, by można w odniesieniu do naszego dzieła użyć określenia „,malarskości”. Ponadto pojawiają się u postaci malowanych przez Mistrza z Wyższego Brodu zadziwiająco zbieżne motywy, wzmacniające wskazaną zależność (il. 1, 6): rurkowe zwisy szaty poniżej kolan i jej meandrujące krawędzie; ostra fałda koszowa (przełamana na osi, o miękkich grzbietach) z boku lewej nogi; podłużne fałdy wykładające się pod stopami; głębsza fałda koszowa między kolanami z charakterystycznym „oklejaniem” jej poła płaszcza; fałdka na osi klatki piersiowej, podwinięte rękawy i wywinięcie podbiciem na torsie; układ materii okrywającej rękę. Na podstawie powyższych analogii można zasugerować przetransponowanie z malarstwa na rzeźbę zarówno motywów, jak i modelunku. Porównania te pozwalają z przekonaniem stwierdzić istnienie zależności stylistycznej pomiędzy twórczością Mistrza z Wyższego Brodu a autorem tytułowej rzeźby, jak i czerpanie z zasobów motywów przez niego stosowanych.

Warto zwrócić uwage również na dzieła malarskie z terenu dawnego państwa krzyżackiego wykazujące czeskie pochodzenie ${ }^{60}$. Szczególnie na te noszące, jak się uważa, ślad twórczości „II Mistrza kwater poliptyku toruńskiego”61.

${ }^{60}$ Np. malowidło ze sceną Koronacji Marii z ok. 1380 r., na ścianie Wielkiego Refektarza w zamku biskupim w Lidzbarku Warmińskim. Malowidło to swoją formą „naśladuje obraz tablicowy”: A.S. Labuda, Malarstwo tablicowe państwa krayzzackiego drugiej połowy XIV wieku, s. 17, 18, il. 7).

${ }^{61}$ Ibidem, s. 88: „II Mistrza retabulum toruńskiego” uważa się za malarza skrzydeł Madonn Szafiastych z: Rogóźna, Klonówki, Sejn. Problematyka rodowodu stylistycznego Ma- 
Spośród nich najlepszym przykładem porównawczym są malowane wnętrza skrzydeł Madonny Szafiastej z Rogóźna ${ }^{62}$. Pojawia się na nich, nieco inny, niż w dziełach Mistrza Wyszobrodzkiego, niewątpliwie zbieżny z szeregiem dzieł lokalnych, typ twarzy - „wyciagniętej” (wraz z zarostem) ku przodowi, o wydatnych oczach z „wypchniętą" wręcz gónną powieką i z bruzdą podkreślająca jej krawędź, z wysuniętymi, wąskimi ustami, z zaakcentowanymi kośćmi policzkowymi. Ten sam typ twarzy reprezentuje oblicze figury toruńskiej, chociaż nie ma ono bezpośrednich analogii w rzeźbie z terenu Prus ${ }^{63}$. To mogłoby potwierdzać czeski (i równocześnie malarski) rodowód stylu twórcy toruńskiego Chrystusa.

Jednak wniosek ten nie rozwiązuje w pełni problemu złożonej genezy artystycznej dzieła, a jedynie naświetla dominujący w niej kompartyment. Brakujących „składników” stylu, decydujących o ostatecznej formie artystycznej rzeźby Chrystusa, należy szukać w środowisku rzeźbiarskim.

Nawiązując do sugerowanych już w starszej literaturze przedmiotu powiązań z kręgiem Madonn na Lwach, m.in. „grupy helskiej” ${ }^{64}$, trzeba w ogóle zwrócić uwagę na dominujące w drugiej połowie XIV wieku na terenie Prus warsztaty określane kręgiem Madonn na Lwach. Podobieństwa

donn Szafiastych na Pomorzu u: R. Ciecholewski, Problematyka badawcza pomorskich Madonn szafkowych, „Studia Pelplińskie”, t. 8, Pelplin 1977, s. 127-152. Poza tymi obiektami są to malowidła: na szafie relikwiarzowej z katedry w Kwidzynie - zaginiona (A.S. Labuda, Malarstwo tablicowe państwa krayżackiego drugiej potowy XIV wieku, s. 85, il. 44), na tryptyku z Fromborka - dawnym ołtarzu głównym ze szpitalnej kaplicy św. Anny - zaginiony (Tamże, s. 86, il. 45). Wszystkie wymienione obiekty pochodzą z 4 ćw. XIV w. (Ibidem, il. $43,44,45$, zob. podpisy pod ilustracjami).

${ }^{62}$ Gwido Chmarzyński, wskazując na Boga Ojca z grupy Tronu Laski jako analogię, nie wziął pod uwagę malowideł ze skrzydeł Madonn Szafiastych.

${ }_{63}$ Ten sam model twarzy zilustrowany na skrzydłach Madonn Szafiastych okazał się niezwykle trwały w snycerce, bo chociaż sparafrazowany, pojawiał się jeszcze w k. XIV i w 1 ćw. XV wieku, np. twarze: postaci grupy Chrystusa z niewiernym Tomaszem z kościoła św. Wojciecha w Lidzbarku Welskim $-3 / 4$ ćw. XIV w. (Tadeusz Chrzanowski, Marian Kornecki, Nieznane rzę́by gotyckie kregu pomorskiego, seria: „Rocznik Historii Sztuki”, nr 8, Wrocław 1970, s. 303-326, s. 317), Chrystusa z Helu i apostołów z grupy Zaśnięcia z tegoż ołtarza - XIV/XV w. (M. Jakubek-Raczkowska, Plastyka średniowieczna od XIII do XVI wieku, s. 52, 54), św. Mikołaja z katedry pw. św. Mikołaja w Elblagu - ok. 1420 r. (M. Jakubek-Raczkowska, Tu ergo flecte genua tua. Sztuka a praktyka religijna swieckich $w$ diecezjach pruskich państwa zakonu krayżackiego do potowy XV wieku, Pelplin 2014, il. 131).

${ }^{64}$ A. Brosig, Plastyka gotycka na Pomorzu, Toruń 1930, s. 5. 
figury Chrystusa z Torunia do tej grupy zabytków moga być wprawdzie związane ze „stylem czasu”, ale moga też wynikać z bliższych kontaktów toruńskiego twórcy $\mathrm{z}$ tą dominująca $\mathrm{w}$ Prusach tradycją. Jej reprezentatywnymi dziełami w regionie sa: Madonna z kościoła św. Elżbiety Węgierskiej w Lubieszewie oraz Madonna z kościoła parafialnego w Jezierniku - 4 ćw. XIV w. ${ }^{65}$ W rzeźbie Chrystusa do cech stylistycznych - wiążących ją z tym kręgiem należą: silna „reliefowość” formy połączona z iluzja głębi; „system światłocieniowy” szaty, jej malarskośćc6; relacja szaty do ciała - przyleganie do niego i zaznaczanie jego kragłości ${ }^{67}$; osiagnięcie iluzji głębi za pomocą licznych diagonali; dekoracyjność szaty, jej stylizacja i linearyzm ${ }^{68}$; niemal pełnoplastyczna głowa w stosunku do ,reliefowego" korpusu, odchylenie głowy ku tyłowi, nachylenie ku przodowi tafli siedziska, kilkuwarstwowe meandry krawędzi szat ${ }^{69}$. $\mathrm{Na}$ rzecz oddziaływania tej tradycji artystycznej, wykorzystującej obficie środki artystyczne stosowane w malarstwie, za artystą toruńskiego przemawiają też argumenty pozastylowe: funkcja ołtarzowa rzeźby ${ }^{70}$; popularność w Prusach nastaw ołtarzowych z przedstawieniem Koronacji Marii ${ }^{71}$. Są zależności wykraczające poza „styl czasu”, ale nie można zakwalifikować Chrystusa do warsztatu, który wykonał czołowe figury kręgu Madonn na Lwach.

65 Z. Białłowicz-Krygierowa, Studia nad snycerstwem XIV w. w Polsce, Katalog, s. 63. Krag pruski nazywany jest również śląsko-pruskim, por.: eadem, Ze studiów nad kregiem Madonn na lwach. Motyw i system, s. 249.

${ }^{6}$ Ibidem, s. 255 i n.: przywołuje malarstwo, przede wszystkim czeskie, jako wzór dla rzeźb tego kręgu.

${ }^{67}$ Ibidem, s. 255-256.

68 Ibidem, s. 253.

${ }^{69}$ Ibidem, s. 254. Poza wyodrębnionymi wyżej założeniami ogólnymi tego kręgu analiza stylistyczno-porównawcza jest zbędna, gdyż figura Chrystusa znacznie odbiega formalnie od wymienionych rzeźb zarówno pod względem typu twarzy (co nie ulega watpliwości), jak i modelunku szat. Problem genezy tzw. pruskiego kręgu Madonn na Lwach jest nadal aktualny; o tym ostatnio: M. Jakubek-Raczkowska, Rzę́ba gdańska pręełomu XIV i XV wieku, Warszawa 2006, s. 49-57.

70 Z. Białłowicz-Krygierowa, Studia nad snycerstwem XIV w. w Polsce, cz. 1, Poczqtki ślaskiej tradycii oltarza szafowego, seria: „Prace Komisji Historii Sztuki”, t. 12, Poznań 1981, s. 26 i n.

71 Np. ołtarz z Grabowa Królewskiego, Bąkowa, Pełcznicy, Ciećmierza itd. (Ibidem, s. $68 \mathrm{i} \mathrm{n})$. 
Pewne cechy stylu toruńskiej rzeźby wymagają zwrócenia uwagi na dzieła włączane w literaturze do kręgu Madonn na Lwach, lecz sytuowane na jego obrzeżach ${ }^{72}$, a wykazujące kilka zbieżności z omawianą figurą: wspominany już zespół ołtarzowy z Helu ${ }^{73}$ oraz rzeźba Chrystusa z niewiernym Tomaszem z kościoła św. Wojciecha w Lidzbarku Welskim ${ }^{74}$.

Obok wcześniej wymienionych w niniejszej pracy cech różniących figurę Chrystusa helskiego ${ }^{75}$ można jeszcze wskazać na bryłę tej rzeźby, której nie „zredukowano” tak silnie jak w dziele toruńskim, a co odstaje od założenia ogólnego kręgu Madonn na Lwach ${ }^{76}$. Formalnie bliższe rzeźbie Chrystusa zdaja się twarze apostołów ze sceny Zaśnięcia Marii z tegoż ołtarza, szczególnie oblicze nieokreślonego apostoła znajdującego się z lewej strony grupy postaci. Do analogii można włączyć: cyzelersko wydobyte szczegóły anatomiczne, wydatne oczy z wydłużonymi zewnętrznymi kącikami, uwypuklone kości policzkowe, wąskie, lekko rozchylone usta, wyraźnie zwrócone głowy sugerujące ruch, układ pukli zarostu ${ }^{77}$. Odmienne są rysy twarzy, bardziej ostre, suche, szczególnie łączenie nasady nosa z linią brwi (zaakcentowanie nasady nosa poprzeczną fałdka), obfitszy zarost i całkowicie inne stylistycznie szaty postaci, które nie są tutaj materiałem porównawczym.

Dziełem, które wg dotychczasowych opinii ${ }^{78}$ ujawnia wczesne świadectwo wpływów Madonn na Lwach, wysoką klasę artystyczną, ale też złożoność stylową i luźny związek ze wspomnianym kręgiem, jest rzeźba

${ }^{72}$ A co za tym idzie - eklektycznymi - typowymi dla późnej fazy kręgu Madonn na Lwach.

${ }^{73}$ M. Jakubek-Raczkowska, Ržeźb̧a gdańska przełomu XIV i XV wieku, s. 57-59; eadem, Plastyka średniowieczna od XIII do XVI wieku, s. 52.

${ }_{74}$ T. Chrzanowski, M. Kornecki, op.cit., s. 317.

75 Natomiast nieulegająca wațliwości zbieżność zastosowanych motywów dla rzeźb Chrystusa z Helu i z Torunia, podobny czas ich powstania (dla ołtarza z Helu - przełom XIV/XV w., por. u: M. Jakubek-Raczkowska, Plastyka średniowiecżna od XIII do XVI wieku, s. 52, 54), przy tym nieduża odległość miejsc ich przeznaczenia, świadczyć może o wzorowaniu się artysty z Helu na znakomitym dziele toruńskim.

${ }^{76}$ Literatura niezmiennie przypisuje temu rzeźbiarzowi warsztat gdański z wpływami sztuki płn. Niemiec i charakterystyczną dla tego obszaru, m.in. dla Lubeki, pewną twardością modelunku, por. u: M. Jakubek-Raczkowska, Plastyka średniowieczna od XIII do XVI wieku, s. 52.

77 Trzeba zaznaczyć, że mamy tu do czynienia ze sceną wieloosobowa, co może wiązać się z mniejszą starannością opracowania szczegółów.

${ }^{78}$ Por. T. Chrzanowski, M. Kornecki, op.cit., s. 317. 
z ołtarza w kościele pw. św. Wojciecha w Lidzbarku Welskim, przedstawiająca Chrystusa z niewiernym Tomaszem (il. 7) ${ }^{79}$. Analogia w tym dziele jest, podobnie jak w poprzednim przykładzie, opracowanie szat i model twarzy. Tkanina jest „ciagliwa”, miękka, o plastycznych, malarsko dekoracyjnych fałdach; przylega do ciała - w partii ud św. Tomasza wręcz je „oklejając”. Oprócz wymienionych już wyżej cech znamiennych dla wyróżnionego wcześniej typu twarzy (na skrzydłach Madonny Szafiastej z Rogóźna), można wskazać na jej niezwykle podobny modelunek: naturalne podkreślenie kości policzkowych, kształt lekko rozwartych ust, typ zarostu. Te analogie - choć znaczne, sytuując figurę toruńską w kręgu powiązań stylowych Madonn na Lwach - nadal nie wyczerpuja problemu genezy jej stylu.

W tym kontekście warto odwołać się do dzieł warsztatów rzeźbiarskich ostatniej ćwierci XIV w. z najbliższego otoczenia toruńskiej figu$\mathrm{ry}^{80}$. Pod względem formalnym szczególną uwage zwraca dzieło uznawane w literaturze za część dawnego wyposażenia kościoła franciszkanów toruńskich - Chrystus w Grobie z ok. 1400 r. ${ }^{81}$ Rzeźba ta może wydawać się nieodpowiednim materiałem porównawczym ze względu na monumentalizm i ukazanie turpicznej twarzy. Jednak trzeba sobie uświadomić cał-

79 Podczas prac inwentaryzacyjnych została znaleziona w neogotyckiej kaplicy we Wlewsku (Ibidem, s. 316).

${ }^{80}$ Do wybranych przykładów reprezentatywnych dzieł w regionie tego czasu należą: Maria z Dzieciątkiem na masce lunarnej z kościoła św. Jakuba w Toruniu - ok. 1370 r., rzeźba wysokiej klasy artystycznej o nierozpoznanej pierwotnej funkcji. Zazwyczaj łączona z warsztatami pomorskimi Madonn na Lwach, jednak różni się od nich znacznym wolumenem bryły (A. Błażejewska, E. Pilecka, op.cit., s. 138, il. 127, s. 142); snycerska pracownia w Brodnicy, do której obok kolegium apostolskiego na konsolach z kościoła św. Katarzyny w Brodnicy włącza się m.in. cztery Święte Dziewice z ołtarza z Pietrzwałdu k. Sztumu (Obecnie powiązanie warsztatowe tych figur z rzeźbionymi kwaterami (sceny Dzieciństwa Chrystusa) jest podważane, por. Z. Białłowicz-Krygierowa, Studia nad snycerstwem XIV w. w Polsce, Katalog, s. 29; M. Jakubek-Raczkowska, Plastyka średniowieczna od XIII do XVI wieku, s. 42-47); przykład spośród nielicznych dzieł rzeźby architektonicznej schyłku XIV w. to zespół wsporników figuralnych z zakrystii kościoła św. Janów w Toruniu z przedstawieniami Chrystusa Bolesnego, Matki Boskiej Bolesnej i świętych - wg Tadeusza Jurkowlańca o wpływach rzeźby parlerowskiej (T. Jurkowlaniec, Gotycka ržeźba architektonicz̨na w Prusach, Wrocław 1989, s. 109). Jednakże nie są to obiekty, które można by uznać za materiał porównawczy.

81 Obecnie w Muzeum Okręgowym w Toruniu. A. Błażejewska, E. Pilecka, op.cit., s. $126,127$. 
kiem inne przeznaczenie tej rzeźby; jej temat - Chrystusa złożonego do grobu, którego rany i cierpienie miało być eksponowane ${ }^{82}$. Twarz Chrystusa w Grobie (il. 8) wykazuje mimo to szereg zbieżności pozwalających na porównanie z rzeźbą Chrystusa zasiadającego na tronie (il. 9): wypukłe gałki oczne i krawędź powieki podkreślona bruzda; nos nieco szerszy w partii środkowej i zaakcentowane skrzydełka nosowe; fałdy nosowo-wargowe; zaznaczone kości policzkowe; wąskie usta o wykroju migdałowym, z wydatnymi wargami, lekko rozwarte, ukazujące linię zębów. Również perizonium może stanowić materiał porównawczy (il. 10): miękki modelunek, relacja szaty do ciała - przyleganie materiału i uwidacznianie jego kształtu, wywinięcie materiału podbiciem na lewym biodrze, centralnie umieszczona ostra fałda koszowa (przełamana na osi), ale o miękkich grzbietach. Zatem być może, na podstawie powyższych zbieżności formalnych, ten sam warsztat, do którego należał twórca toruńskiej figury bądź któryś z zatrudnionych w nim rzeźbiarzy, uczestniczył w tworzeniu rzeźby Chrystusa w Grobie. Za tą hipotezą przemawia również to samo środowisko zakonne, dla którego były przeznaczone oba dzieła. Czy oznaczałoby to po części czeski rodowód figury Chrystusa w Grobie? ${ }^{83}$ Niekoniecznie,

82 Artysta musiał spełnić wymagania zleceniodawców i zamiast idealizowanej twarzy Chrystusa z Koronacji Marii, pokazać przebytą mękę i zbolałą twarz. Taki efekt uzyskano głębszymi bruzdami na twarzy, „wysuszeniem” ciała, „zapadniętą” oprawą oczu.

${ }^{83}$ W literaturze pojawiła się niegdyś taka sugestia: K. Kluczwajd, Chrystus w Grobie, w: Ars Sacra. Dawna sæztuka diecezji torunskiej, Katalog wystawy, Toruń 1993, s. 41. Raczkowscy przyjmują za analogię formalną kamienna plastykę norymberską z ostatniej tercji XIV wieku, m.in. dekorację fasady zachodniej kościoła pw. Św. Wawrzyńca, ale pojawia się również w tej samej pracy sugestia o czesko-śląskich inspiracjach: M. Jakubek-Raczkowska, J. Raczkowski, Gotycka figura Chrystusa w Grobie i jej miejsce w przestrzeni liturgicznej kościoła francisžkanów w Toruniu, Drieje i skarby kościoła Mariackiego w Toruniu, „Materiały z konferencji przygotowanej przez Toruński Oddział Stowarzyszenia Historyków Sztuki przy współpracy Instytutu Zabytkoznawstwa i Konserwatorstwa Uniwersytetu Mikołaja Kopernika - Toruń 14-16 kwietnia 2005)", red. K. Kluczwajd, Toruń 2005, s. 181-202, s. 190, 201 (por. też niepublikowany tekst: M. J. Raczkowscy, „Chrystus w Grobie z kościoła NMP w Toruniu”, mps, Toruń 2002, Archiwum Miejskiego Konserwatora Zabytków w Toruniu). W późniejszej pracy Raczkowscy podtrzymują obie hipotezy. Jednocześnie włączają do warsztatu Chrystusa w Grobie gotyckie rzeźby w Świerczynkach o znamionach stylu Madonn na Lwach: J. Raczkowski, M. Jakubek-Raczkowska, Gotyckie ręé́by z. kościoła w Świercaynkach. Praycaynek do badan nad średniowiecznym dziedzictwem Torunia, [w:] Stare i nowe dziedzictwo Torunia, Toruń 2013, s. 108-119, s. 116. 
jako dzieło wykonane na miejscu, w Toruniu, mogło być efektem „zejścia się” różnych wpływów ${ }^{84}$.

W oparciu o powyższe racje, możemy stwierdzić, że styl twórcy rzeźby Chrystusa w przeważającym stopniu ukształtowało malarstwo czeskie, a przede wszystkim twórczość Mistrza z Wyższego Brodu i warsztatów blisko z nim związanych. Dzieła czeskiego artysty wyróżniają się spośród tamtejszego malarstwa ok. połowy XIV wieku linearna dekoracyjnością obfitych szat, ale jednocześnie dosyć cienkich na tyle, by w charakterystyczny sposób uwidocznić kształty ciała. Tym samym można zrozumieć sugerowanie przez wcześniejszych badaczy pewnych analogii z rzeźbą kamienną, zarówno tzw. Mistrza sarkofagu św. Seweryna z Erfurtu, jak i tą wcześniejszą górnoreńską i szwabską z 1. 30., 40. XIV stulecia - o kunsztownych, obfitych fałdowaniach szat podkreślających kształt ciała, np. w tympanonie Liebfrauenkirche w Esslingen ${ }^{85}$. Cechy tej tradycji rzeźby monumentalnej nosi bowiem także malarstwo Mistrza z Wyższego Brodu w związku ze wspólnym dla nich odległym podłożem, jakim jest sztuka francuska ${ }^{86}$.

Niewątpliwe, ale też niezaskakujące ze względu na popularność w tym regionie, sa wpływy tradycji Madonn na Lwach, wprawdzie sytuujące rzeźbę Chrystusa na obrzeżach tego kręgu, lecz świadczące o dobrej znajomości tej tradycji artystycznej przez naszego artystę ${ }^{87}$. Biorąc pod uwage analogie, jakie zachodzą między tytułową rzeźbą a miejscowymi zabytkami, należy przypuszczać, że rzeźbiarz toruński najpewniej pracował w regionie i nie można raczej mówić ani o imporcie dzieła, ani twórcy. Lokalizując figurę Chrystusa pomiędzy tymi analogiami -

${ }^{84}$ Zastanawiające jest jednakże podobieństwo w typie figury i układzie perizonium między: Chrystusem w Grobie a monumentalnym malowidłem Chrystusa przy kolumnie - na jednej z przypór tego kościoła.

85 Por. u: R. Suckale, Die Hofkeunst Kaiser Ludwigs des Bayern, München 1993, s. 119.

${ }^{86}$ J. Pešina, Mistr Vyšebrodského cykelu, Praha 1982, s. 50.

${ }^{87}$ Styl rzeźby Chrystusa z Koronacji Marii potwierdza po raz kolejny, jak silnie zakorzeniona była, jak szeroki i długotrwały miała zasięg tradycja warsztatowa Madonn na Lwach, wymagająca dalszych szczegółowych badań. Wprawdzie w przedstawionym materiale porównawczym, jak i w omawianej figurze Chrystusa, pokrewieństwo to jest dalekie, ale tym bardziej widać, na ile popularne były niektóre ogólne założenia tej grupy stylowej. 
twórczością Mistrza z Wyższego Brodu, wczesną rzeźbą Lidzbarka Welskiego a późniejsza - z Helu, można określić czas powstania toruńskiej rzeźby na ok. 1370-1380 r. „Czeskie” cechy stylu swojej twórczości wyniósł najpewniej z nauki w Czechach, ale jego styl ukształtował się ostatecznie na miejscu, w Toruniu (w Prusach?), w kontakcie z tutejszymi warsztatami rzeźbiarskimi.

\section{Summary}

\section{The sculpture of Christ from Mary's Coronation group of the maternal altar in St. Mary's Virgin Assumption Church in Torun. The problem of style}

The aim of this work was to recognize the Christ's sculpture style sources of old - time altar coming from Franciscan St. Mary's Church in Torun.

This sculpture is particularly important because of its high artistic class and its compound style which has not got any direct analogies on the Teutonic Prussia area so far.

The verification of hitherto hypothesis was the beginning for the stylistic comparative analyses. First of all, Chmarzyński's analogies between Christ's figure from Torun and from altar in Hel Peninsula and also from Erfurt sculptures, so called 'Severimeister', pointed by another researcher (Schmid) - were partly essential and they both were taken for the ground in further analyse.

However, for closer description of the artistic origin of Christ's figure was taken the style of painted parts (or segments) from the maternal altar.

Consequently, it was noticed the similarity between Christ's sculpture and the style of Chech's Master from Vyššiho Brodu (the main point was the comparison of the arrangement of robes). So it can be said that the influence of Czech's Master on Christ's sculpture in Torun is very important and essential.

The next point were the searches for analogies in regional sculpture because of the complexity of artistic origin discussed above Christ's figure. As the result, this article presents other elements of described style - the style of so called Madonna's on Lions circle (it was popular in Teutonic Prussia) and the other style of sculptures situated on the edge of this workshop circle by other researchers, for instance the altar from Hel and the sculpture from Lidzbark Welski; also - the local work, as the Christ in the Grave sculpture from St. Mary's Church in Torun.

All the objects, included to the comparative analyses, are simultaneously the indicators in attempt of dating for this described sculpture on about 1370-1380. 


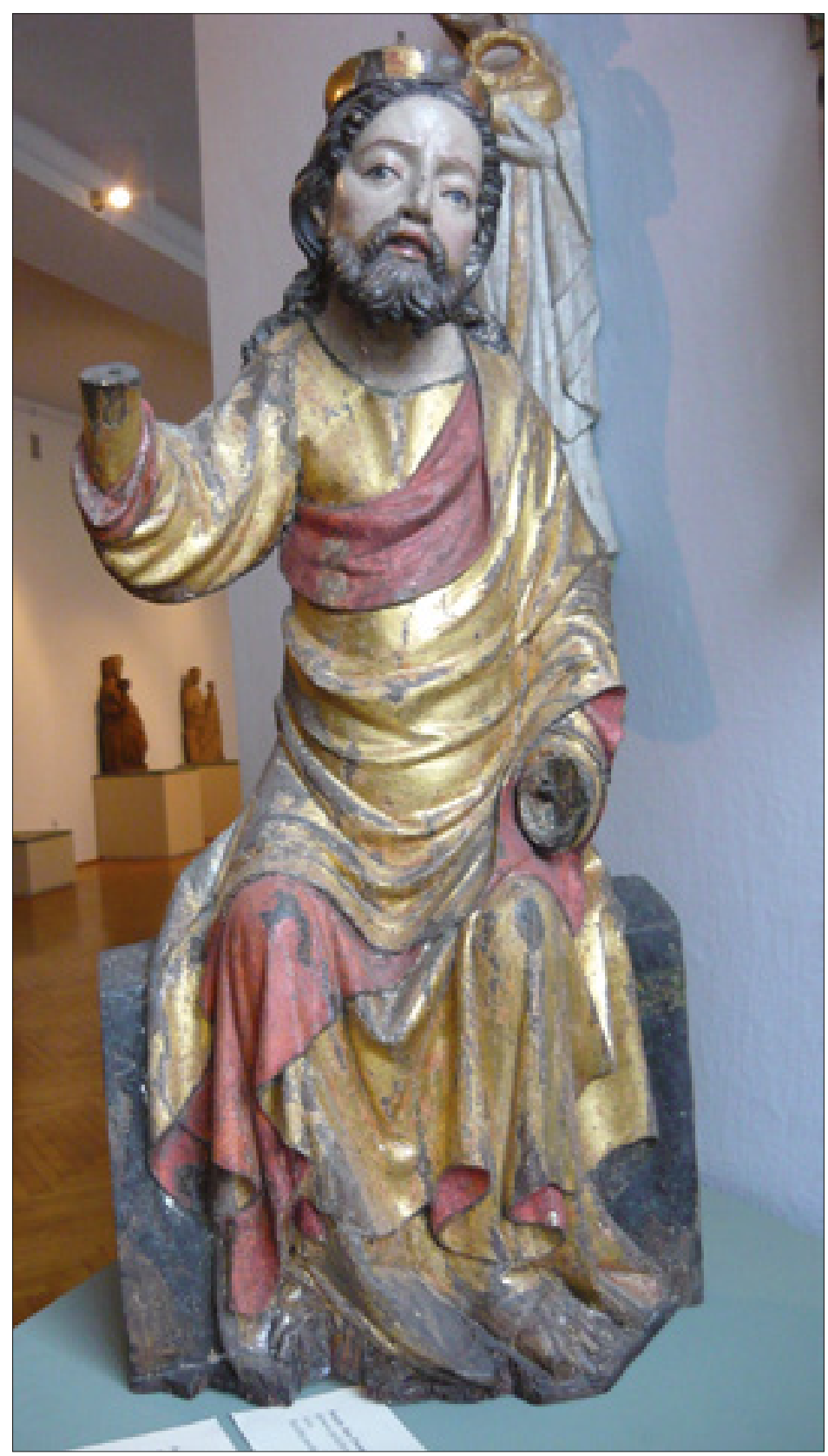

Il. 1. Chrystus z grupy Koronacji Marii z dawnego ołtarza głównego kościoła NMP w Toruniu (Muzeum Diecezjalne w Pelplinie), widok frontalny, fot. Monika Dzienis 


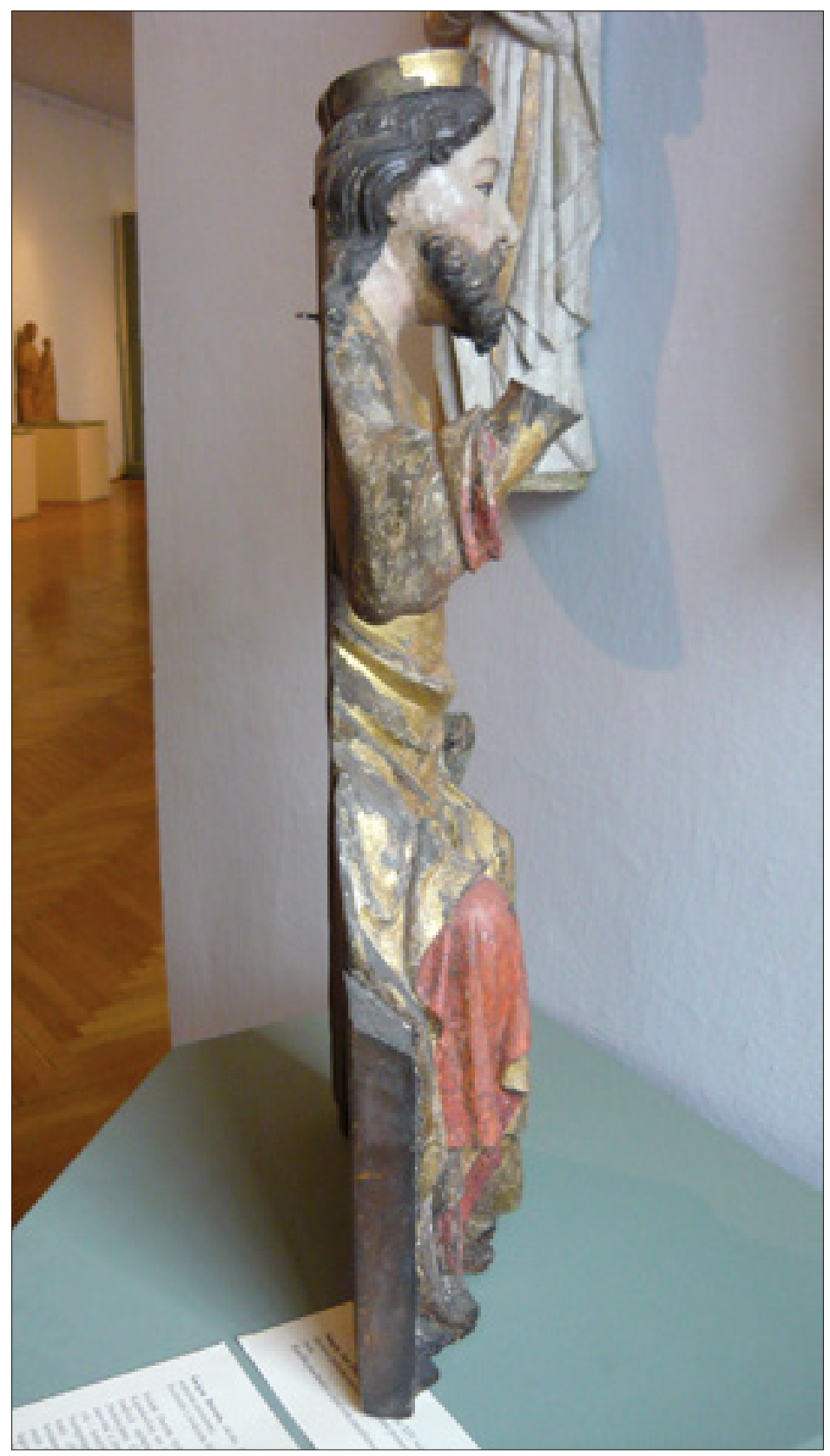

il. 2. Chrystus z grupy Koronacji Marii z kościoła NMP w Toruniu (Muzeum Diece zjalne w Pelplinie), prawy profil, fot. Monika Dzienis 


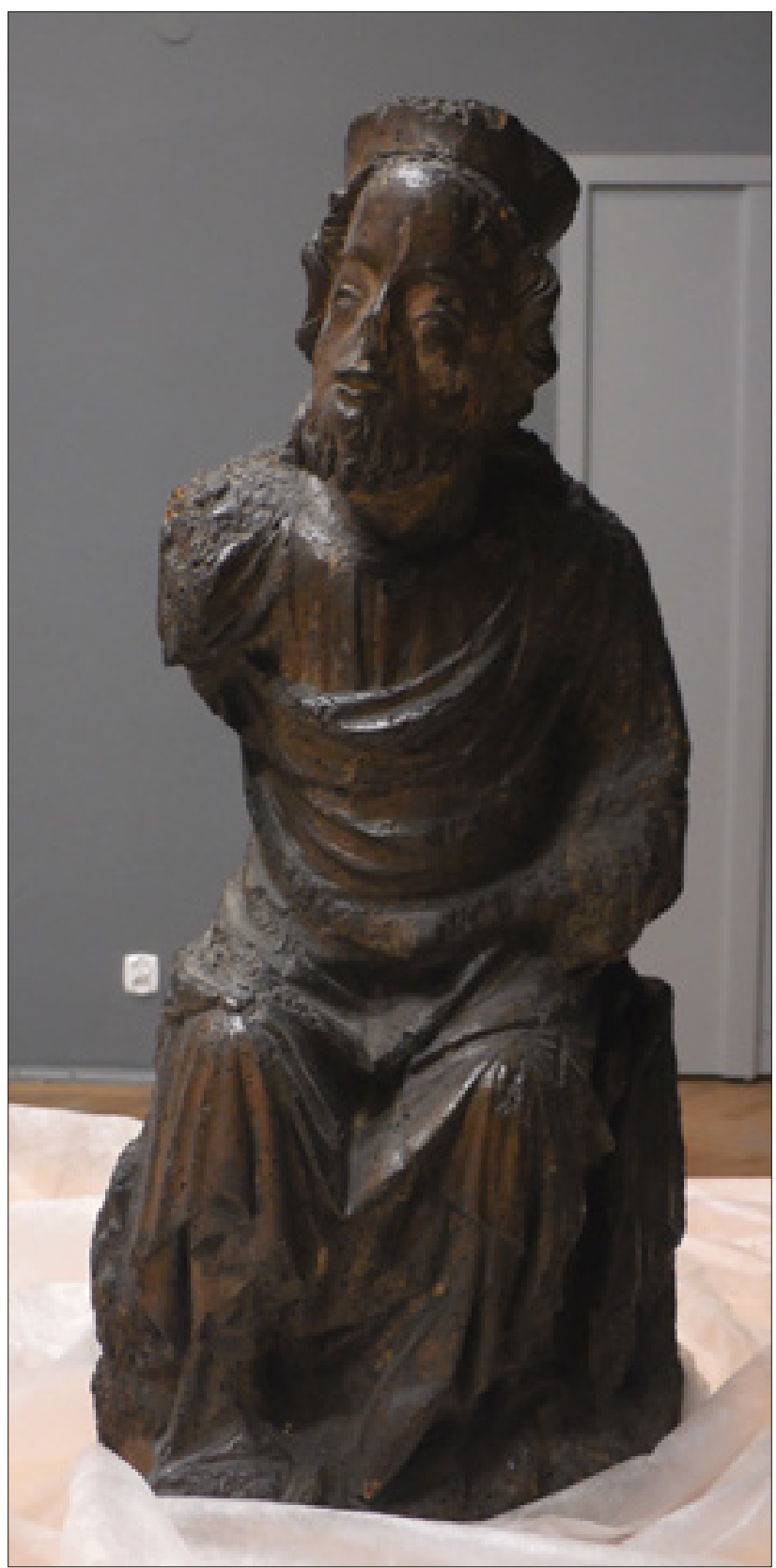

Il. 3. Chrystus z grupy Koronacji Marii z ołtarza w Helu (Muzeum Narodowe w Gdańsku), fot. Monika Dzienis 


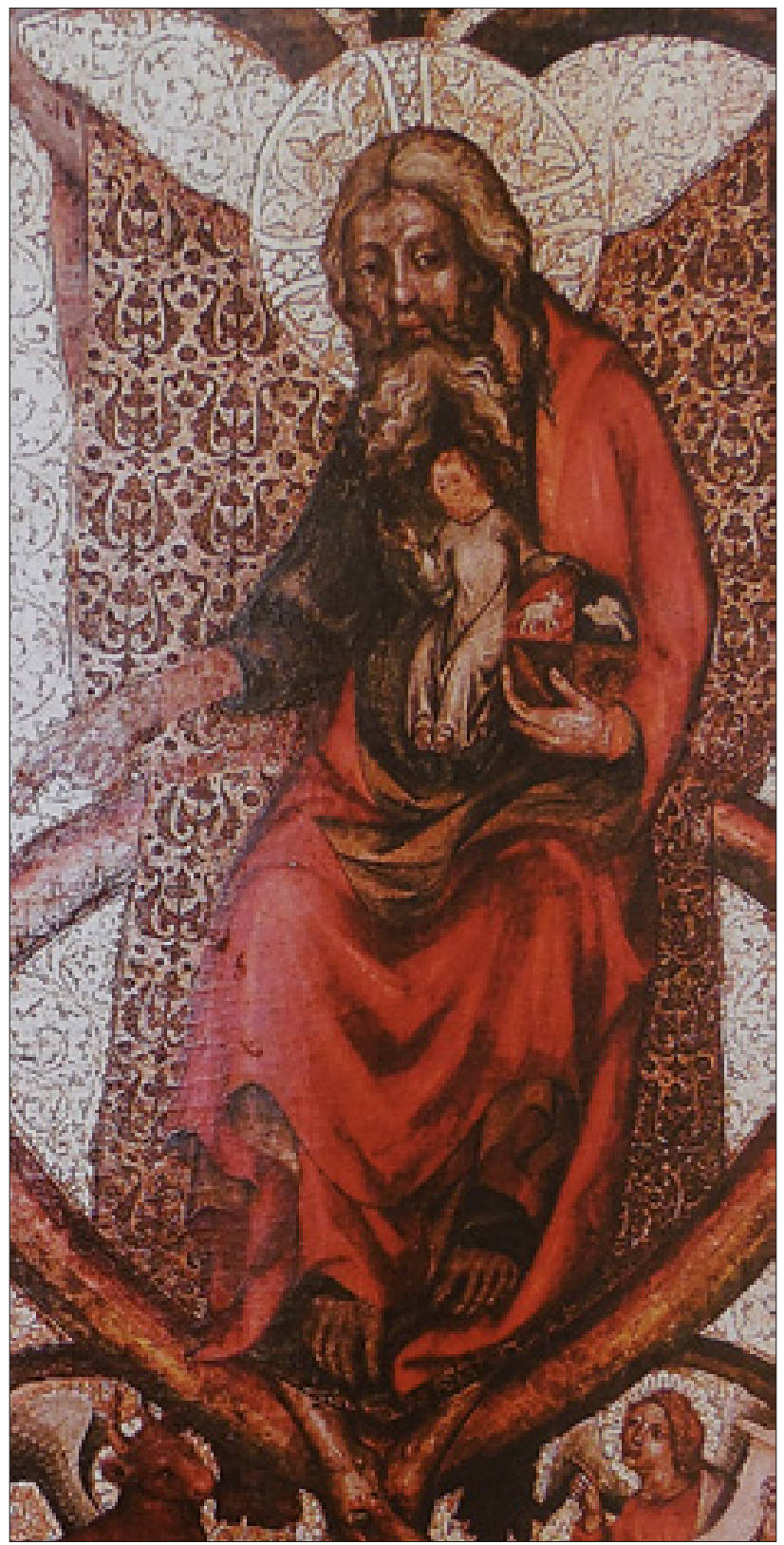

Il. 4. Fragment Trójcy Św., kwatera dawnego ołtarza głównego z kościoła NMP w Toruniu (Muzeum Diecezjalne w Pelplinie), wg J. Raczkowski, Sztuka gotycka w Toruniu, Toruń 2003 , il. 70 , s. 70 


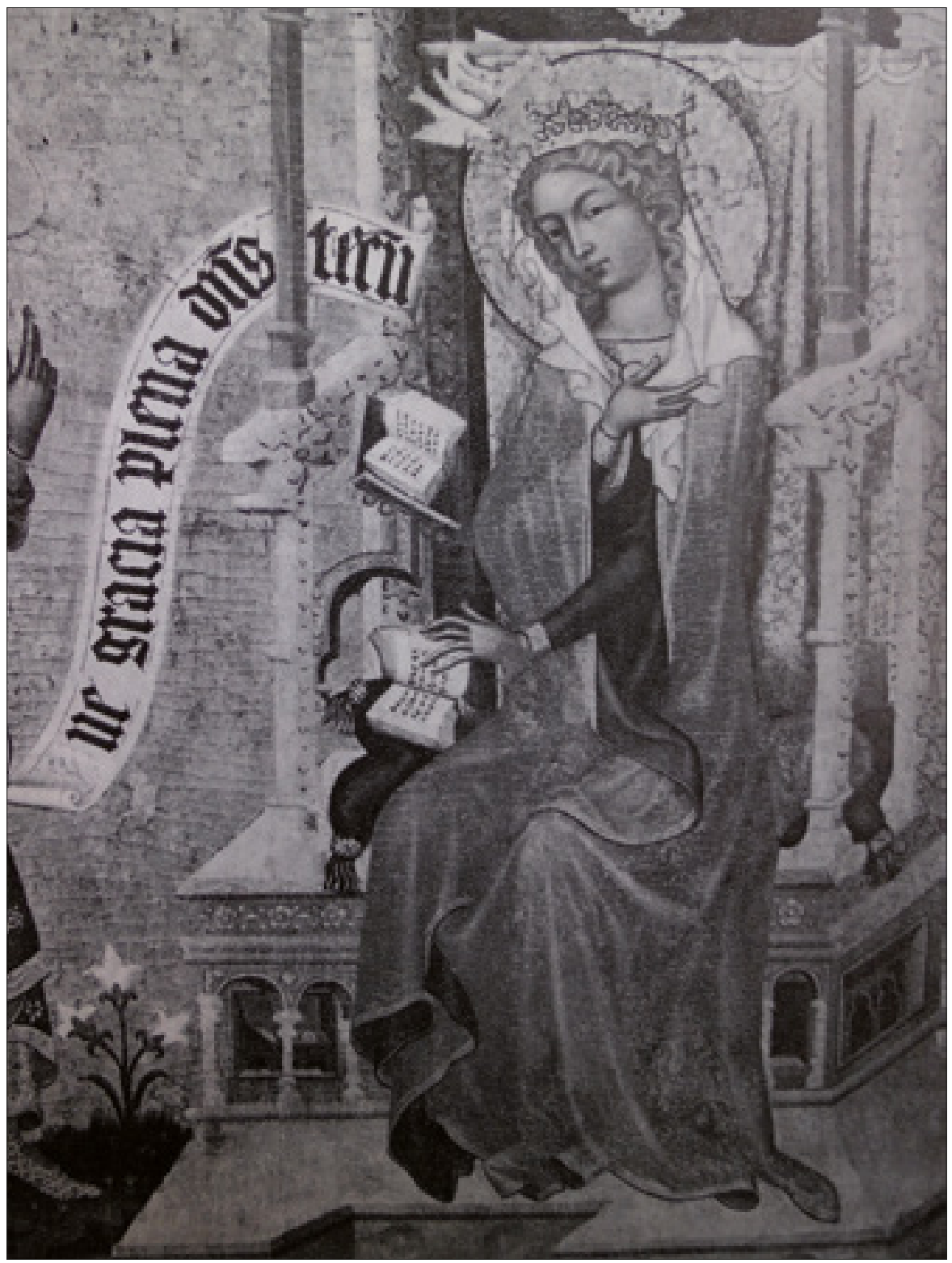

Il. 5. Fragment sceny Zwiastowania NMP, Mistrz z Wyższego Brodu, wg J. Pešina, Mistr Vyšebrodského cyklu, Praha 1982, il. 1 
[100]

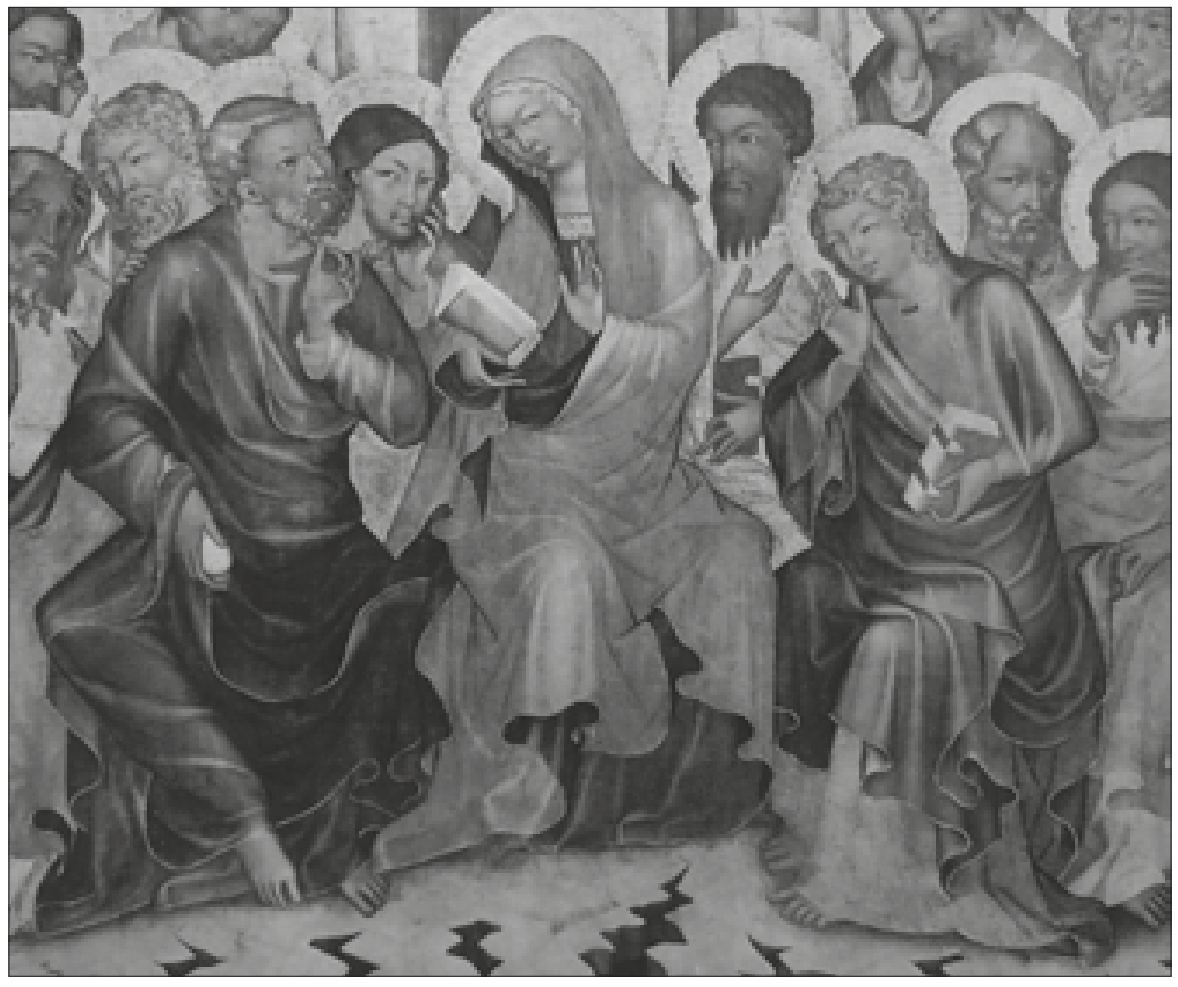

Il. 6. Fragment sceny Zesłania Ducha Św., Mistrz z Wyższego Brodu, wg J. Pešina, Mistr Vyšebrodského cyklu, Praha 1982, il. 63 


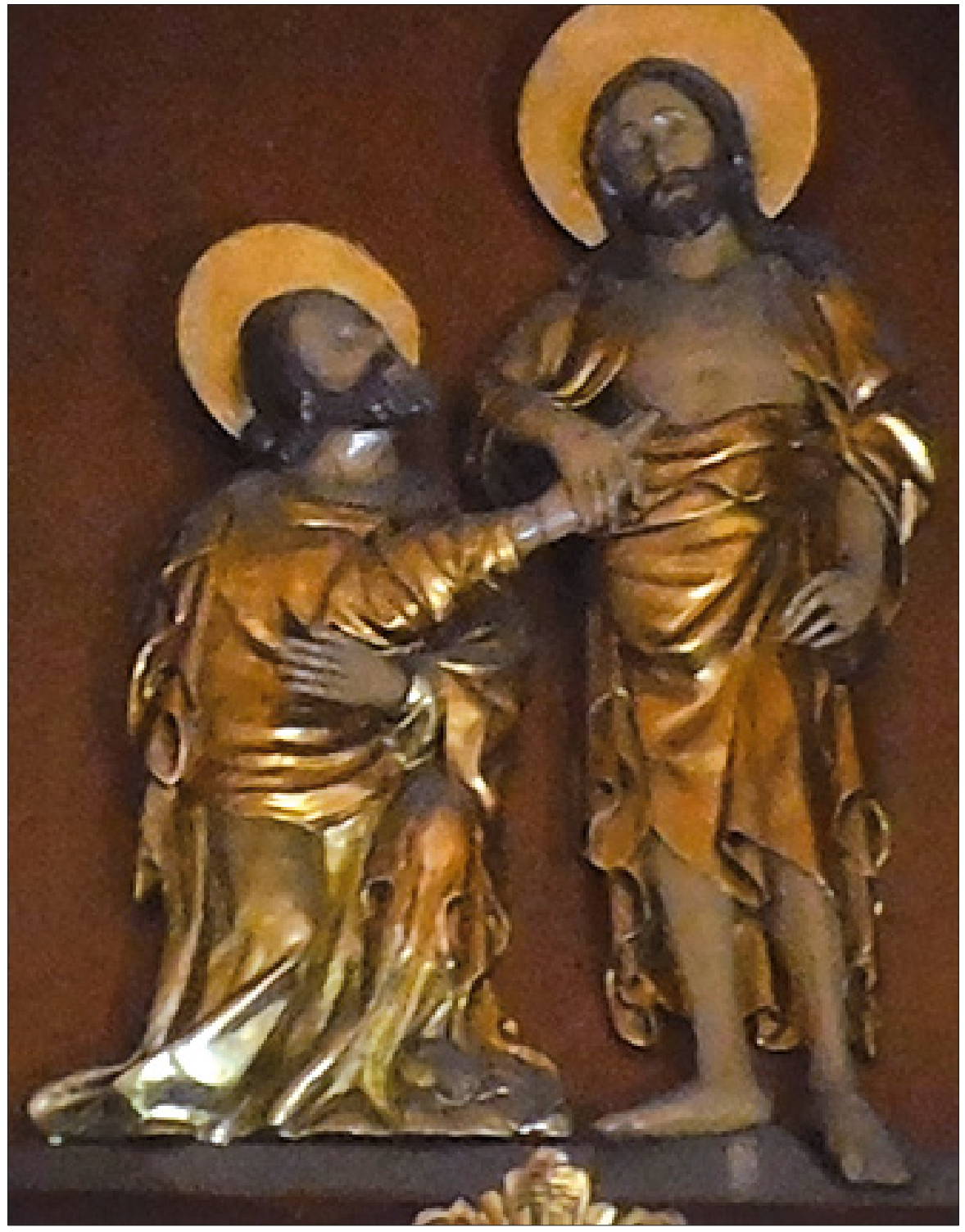

Il. 7. Chrystus z niewiernym Tomaszem z kościoła św. Wojciecha w Lidzbarku Welskim, fot. Monika Dzienis 


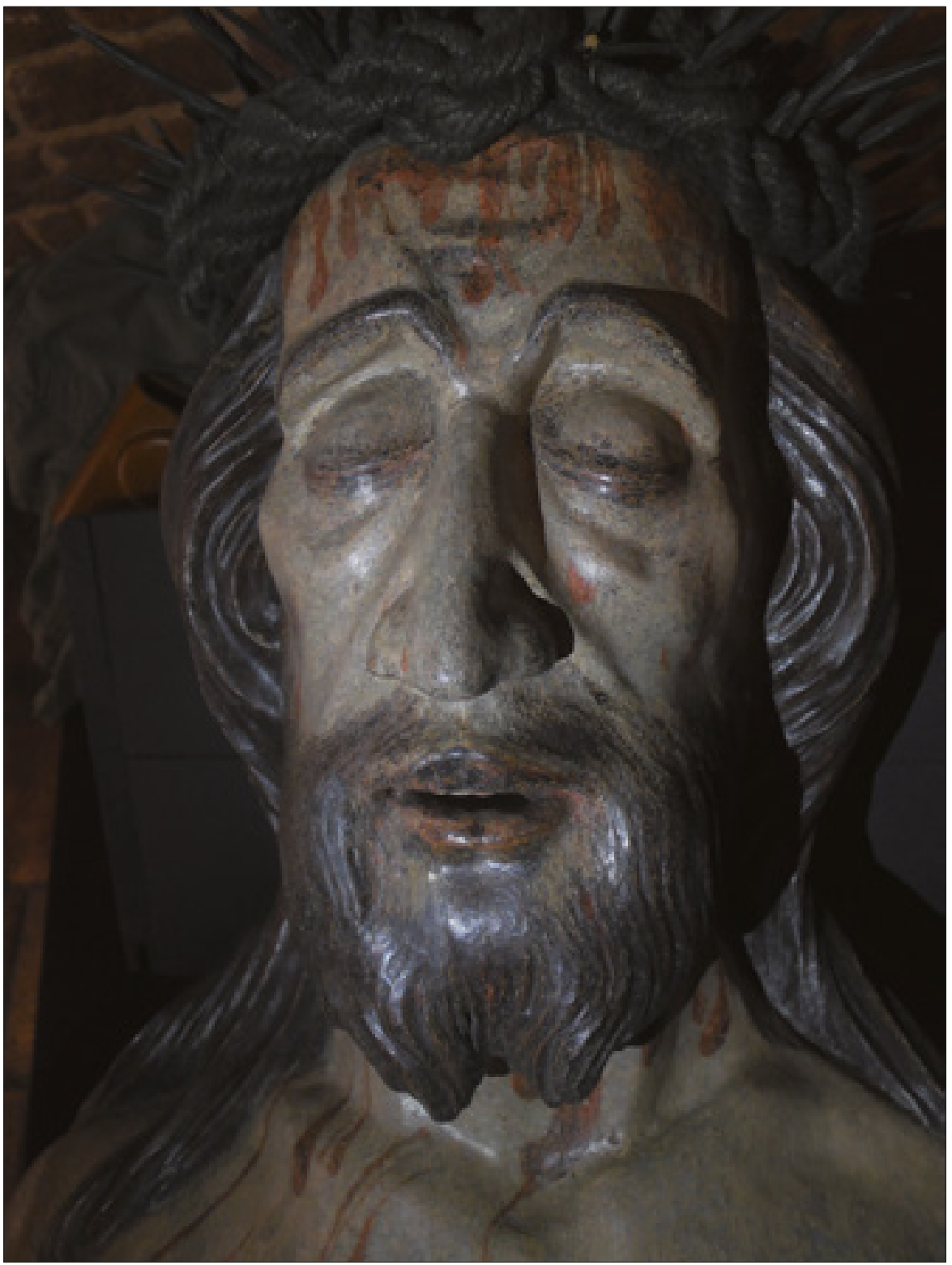

Il. 8. Chrystus w Grobie z kościoła NMP w Toruniu (Muzeum Okręgowe w Toruniu), fot. Monika Dzienis 


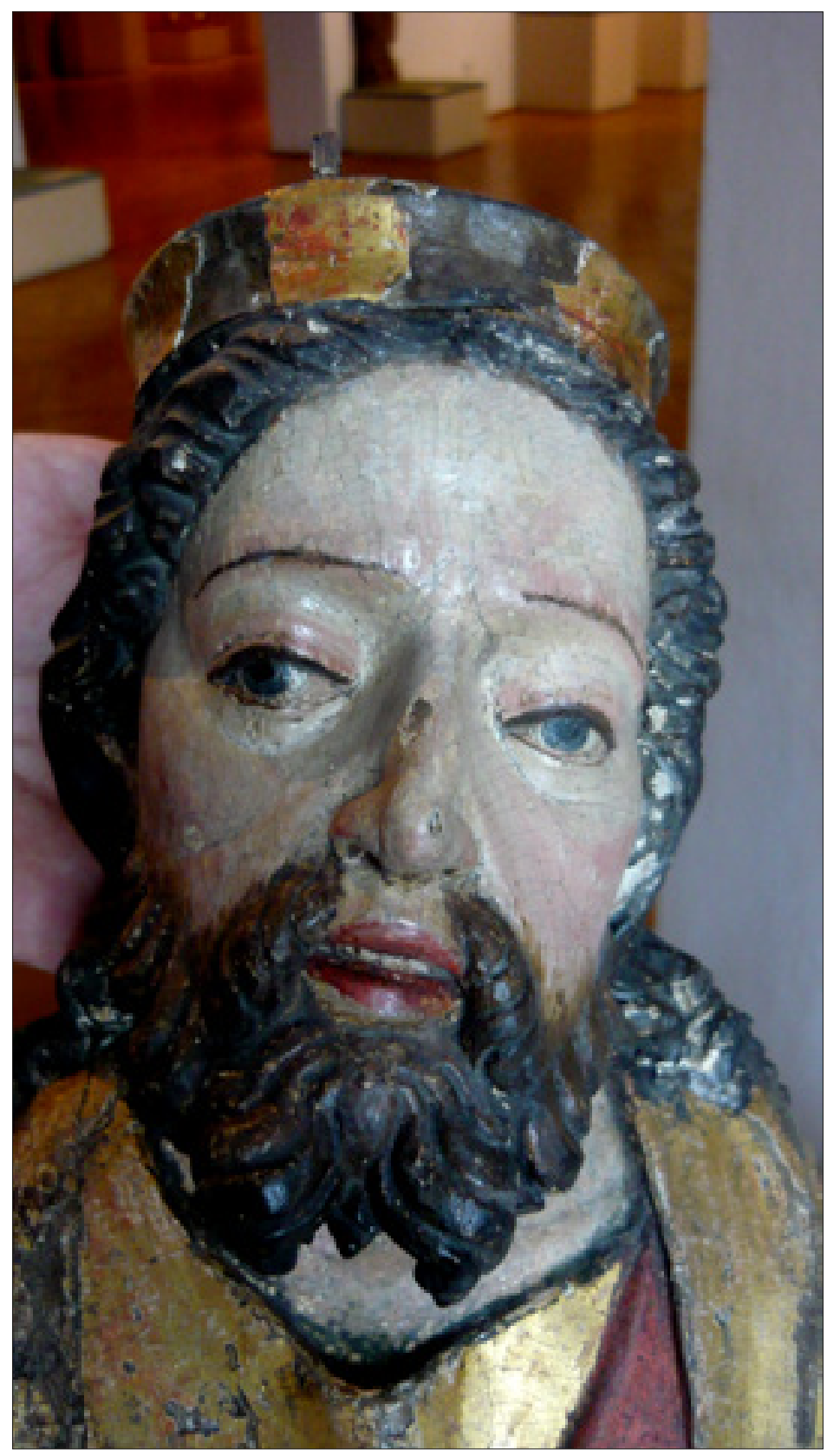

Il. 9. Chrystus z grupy Koronacji Marii z kościoła NMP w Toruniu (Muzeum Diecezjalne w Pelplinie), fot. Monika Dzienis 


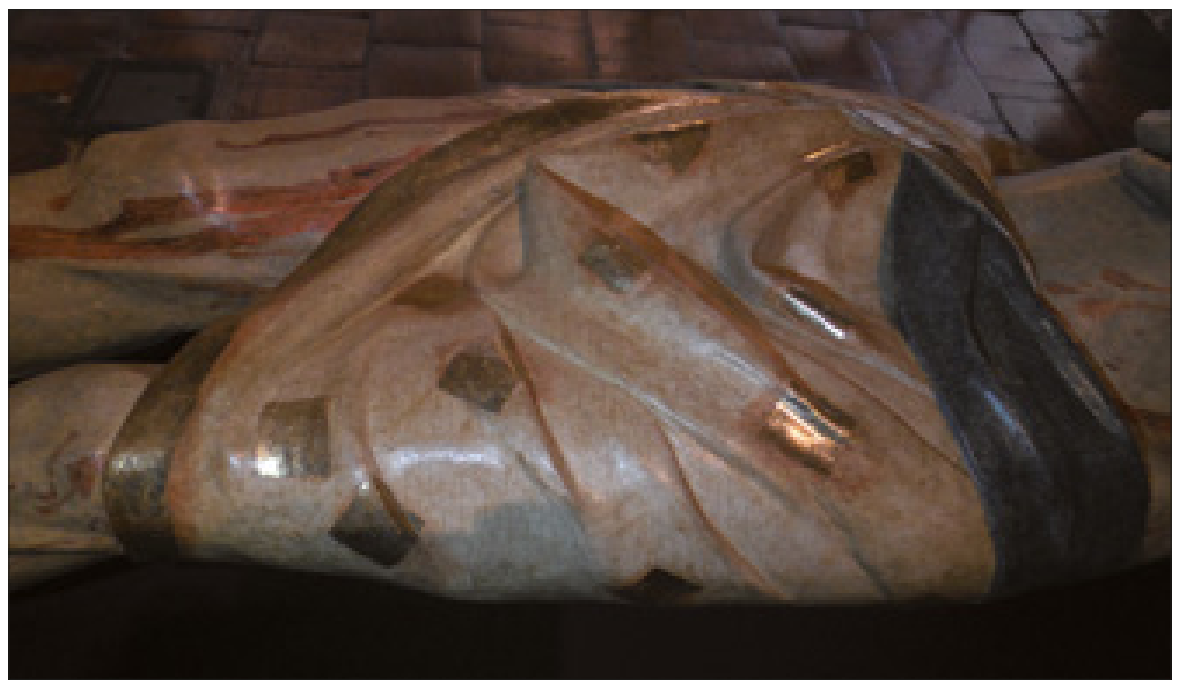

Il. 10. Chrystus w Grobie z kościoła NMP w Toruniu (Muzeum Okręgowe w Toruniu), perizonium, fot. Monika Dzienis 